\title{
Schumpeter meeting Keynes: A policy-friendly model of endogenous growth and business cycles
}

\author{
Giovanni Dosi ${ }^{\mathrm{a}, \mathrm{b}, *}$, Giorgio Fagiolo ${ }^{\mathrm{a}}$, Andrea Roventini ${ }^{\mathrm{c}, \mathrm{a}}$ \\ a Laboratory of Economics and Management, Sant'Anna School of Advanced Studies, Pisa, Italy \\ ${ }^{\mathrm{b}}$ MIoIR, University of Manchester, UK \\ ${ }^{\mathrm{c}}$ Department of Economics, University of Verona, Italy
}

\section{A R T I C L E I N F O}

\section{Available online 23 June 2010}

JEL classification:

E32

E6

$\mathrm{O} 3$

04

\section{Keywords:}

Endogenous growth

Business cycles

Growth policies

Business cycle policies

Evolutionary economics

Agent-based computational economics

Empirical validation

\begin{abstract}
A B S T R A C T
This paper studies an agent-based model that bridges Keynesian theories of demandgeneration and Schumpeterian theories of technology-fueled economic growth. We employ the model to investigate the properties of macroeconomic dynamics and the impact of public polices on supply, demand and the "fundamentals" of the economy. We find profound complementarities between factors influencing aggregate demand and drivers of technological change that affect both "short-run" fluctuations and longterm growth patterns. From a normative point of view, simulations show a corresponding complementarity between "Keynesian" and "Schumpeterian" policies in sustaining long-run growth paths characterized by milder fluctuations and relatively lower unemployment levels. The matching or mismatching between innovative exploration of new technologies and the conditions of demand generation appear to suggest the presence of two distinct "regimes" of growth (or absence thereof) characterized by different short-run fluctuations and unemployment levels.
\end{abstract}

(c) 2010 Elsevier B.V. All rights reserved.

\section{Introduction}

This work studies an agent-based model (ABM) of endogenous growth and business cycles and explores its properties under different public policies impacting on supply, demand, and the "fundamentals" of the economy.

The model addresses three major, interrelated, questions. First, it investigates the processes by which technological innovations affect macro-variables such as unemployment rates and, in the longer term, growth rates. In the current macroeconomic jargon, we explicitly model a firm-specific, endogenous generation of supply shocks, their diffusion and the ways they ultimately drive macro-aggregates. Together with this "Schumpeterian" question, second, we ask how such endogenous changes in the "fundamentals" of the economy interact with demand conditions. This is a basic "Keynesian" question. How does aggregate demand modulates the diffusion and the macro-impact of technological innovations? And, conversely, how does it affect, if at all, the amount of search and the degree of exploitation of innovation opportunities themselves? Third, we explore long-term effects of demand conditions. Is the long-term growth just driven by changes in the technological "fundamentals"? Or, can variations in aggregate demand influence future dynamics? And, ultimately, can one identify multiple growth paths whose selection depends on demand and institutional conditions-determining, e.g. fiscal policies.

\footnotetext{
* Corresponding author at: Sant'Anna School of Advanced Studies, Piazza Martiri della Libertà 33, I-56127 Pisa, Italy. Tel.: +39050883326; fax: +39050883344 .

E-mail addresses: gdosi@sssup.it (G. Dosi), giorgio.fagiolo@sssup.it (G. Fagiolo), andrea.roventini@univr.it (A. Roventini).
} 
In the analysis that follows, we extend the model presented in Dosi et al. (2006a, 2008), which we use also as a sort of "policy laboratory" where both business-cycle and growth effects of alternative public interventions may be evaluated under different techno-economic scenarios. In that, the model allows to experiment with an ensemble of policies, related to the structural features of the economy (concerning, e.g., technology, industry structure and competition) on the one hand, and to demand macro-management, on the other.

Historically, a major divide has emerged in macroeconomics theories. Long-run approaches have traditionally dealt with growth issues in a strict sense, trying to account for (broken-linear or stochastic) trends present in macro time series, while leaving to "short-run" models the task of explaining economic fluctuations around the trend. An early example is the way the IS-LM interpretation of Keynes (Hicks, 1937) and the models rooted in Solow (1956) found their division of labor addressing business cycles and growth, respectively. ${ }^{1}$

Since then, the balance has been shifting over time. At one extreme, the "new classical economics" has boldly claimed the irrelevance of any "Keynesian" feature of the economy. New Keynesian models have defended the turf of "nonfundamental" fluctuations most often on the grounds of informational and behavioral frictions (an insightful overview is in Blanchard, 2009), with just a minority holding the view that such "imperfections" are in fact structural, long-term characteristics of the economy (see Akerlof and Yellen, 1985; Greenwald and Stiglitz, 1993a, b; Akerlof, 2002, 2007, among them). Lacking a better name, let us call the latter Hard New Keynesians, HNK henceforth.

More recently, the new neoclassical synthesis between real business cycle (RBC) and a major breed of New Keynesian models has refined the interactions and the territorial divisions between "fundamental dynamics" and higher frequency, "non-fundamental" shocks within the dynamic stochastic general-equilibrium (DSGE) theoretical family (cf. the classic Woodford, 2003; Galí and Gertler, 2007). In fact, DSGE models feature a core with an RBC engine to which one may easily add sticky prices, imperfect competition, monetary-policy (Taylor-like) rules, and whatever can be imaginatively squeezed into the underlying "structural model".2 Indeed, there is hardly any Schumpeter in terms of endogenous innovation in DSGE models.

From a quite different angle, endogenous growth models, notwithstanding very different features (from Romer, 1990 to Aghion and Howitt, 1992 and Dinopoulos and Segerstrom, 1999), possess an implicit or explicit Schumpeterian engine: innovation and thus the dynamics in the "technological fundamentals" of the economy is endogenous. At the same time, "non-fundamental" (e.g. demand-related) fluctuations do not appear in this family of models. Refinements, such as Aghion and Howitt (1998), ${ }^{3}$ do entail equilibrium fluctuations wherein Keynesian features do not play any role. ${ }^{4}$

Somewhat similarly, evolutionary models, as pioneered by Nelson and Winter (1982), are driven by a Schumpeterian core with endogenous innovation, but do largely neglect too any demand-related driver of macroeconomic activity. ${ }^{5}$

The model which follows, shares evolutionary roots, but in tune with HNK insights (cf. for example Stiglitz, 1994) tries to explore the feedbacks between the factors influencing aggregate demand and those driving technological change. By doing that we begin to offer a unified framework jointly accounting for long-term dynamics and higher frequencies fluctuations.

The model is certainly post-Walrasian (Colander, 2006; Colander et al., 2008) meaning that it goes beyond the purported Walrasian foundations squeezed into the representative-agent assumption nested in DSGE models and the general commitment to market clearing. In that, well in tune with the growing literature on agent-based computational economics (ACE; see Tesfatsion and Judd, 2006; LeBaron and Tesfatsion, 2008), the model meets Solow's (2008) plea for microheterogeneity: a multiplicity of agents interact without any ex ante commitment to the reciprocal consistency of their actions. ${ }^{6}$

Furthermore, the model-alike most evolutionary ABMs-is "structural" in the sense that it explicitly builds on a representation of what agents do, how they adjust, etc. In that, it is as far as the DSGE perspective from "old Keynesian" models studying the relations amongst aggregate variables without any explicit microfoundation. At the same time, our commitment is to "phenomenologically" describe microbehaviors as close as one can get to available microevidence. Akerlof's (2002) advocacy of a "behavioral microeconomics", we believe, builds on that notion. In fact, this is our first fundamental disciplining device. A second, complementary one involves the ability of the model jointly to account for an ensemble of stylized facts regarding both "micro/meso" aggregates such as indicators of industrial structures (e.g. firm size distributions, productivity dispersions, firm growth rates) together with macro statistical properties (including rates of output growth, output volatility, unemployment rates, etc.).

\footnotetext{
${ }^{1}$ For an interesting reconstruction of the econometric counterpart of such a divide in the 1930s and 1940s debate, see Louca (2001).

2 As Blanchard (2009, p. 26) puts it, "To caricature only slightly: a macroeconomic article today follows strict, haiku-like, rules: it starts from a general equilibrium structure, in which individuals maximize the expected present value of utility, firms maximize their value, and markets clear. Then, it introduces a twist, be it an imperfection or the closing of a particular set of markets, and works out the general equilibrium implications. It then performs a numerical simulation, based on calibration, showing that the model performs well. It ends with a welfare assessment."

${ }^{3}$ See also Aghion et al. (2010), Aghion and Marinescu (2007) and Aghion et al. (2008).

${ }^{4}$ Ironically, given the lack of stability of "new growth" trajectories, "Keynesianism" could show its full force. We shall go back to this point below.

5 See, however, the exceptions of Dosi et al. (1994) and Fagiolo and Dosi (2003). Cf. Dawid (2006) for an exhaustive review of ABMs of innovation and technological change.

${ }^{6}$ For germane ABMs with both some Keynesian and Schumpeterian elements see Verspagen (2002), Ciarli et al. (2008), Saviotti and Pyka (2008), and the discussion in Silverberg and Verspagen (2005).
} 
Our work shares many ingredients with (and in many ways is complementary to) the research project carried on within the European project EURACE (http://www.eurace.org), which features a large-scale ABM aiming at capturing the main characteristics of the European economy and addressing European-policy analyses (Deissenberg et al., 2008; Dawid et al., 2008). Unlike EURACE models, however, we keep the scale of the system relatively small, in line with traditional macroeconomic ABMs with little overall calibration exercises, albeit with attention to empirically sound microrules and interaction mechanisms.

The model below describes an economy composed of firms, consumers/workers and a public sector. Firms belong to two industries. In the first one, firms perform R\&D and produce heterogeneous machine tools. Firms in the second industry invest in new machines and produce a homogenous consumption good. Consumers sell their labor to firms in both sectors and fully consume the income they receive. The government levies taxes on workers' wages and firms' profits and it provides unemployed workers with a fraction of the market wage.

As customary in evolutionary/ACE perspectives, the policy framework studied here is explored via computer simulations. To overcome the well-known problems related to sensitivity to the choice of parameters, possibly arising in $\mathrm{ABMs}{ }^{7}$ we look for policy implications that: (i) are robust to reasonable changes in the parameters of the model; (ii) refer to model setups and parametrizations wherein the output of the model is empirically validated (i.e., simulated microeconomic and macroeconomic data possess statistical properties similar to those empirically observed in reality). We consider this as a value added of our study, as very often in the literature policy experiments are performed without imposing any ex ante empirical-validation requirement on the model (Fukac and Pagan, 2006; Canova, 2008; Fagiolo and Roventini, forthcoming). Policy configurations are captured by different "control" parameters and different institutional, market or industry setups. The impact of different policies is then quantitatively assessed in terms of ensuing aggregates such as average output growth, output volatility, average unemployment, etc. One of the main insights stemming from our extensive policysimulation exercises is a vindication of a strong complementarity between Schumpeterian policies addressing innovative activities and Keynesian demand-management policies. Both types of policies seem to be necessary to put the economy into a long-run sustained growth path. Schumpeterian policies potentially foster economic growth, but they do not appear to be able alone to yield sustained long-run growth. In a broad parameter region, "fundamental" (endogenously generated) changes in technology are unable to fully propagate in terms of demand generation and ultimately output growth. By the same token, demand shocks (in the simplest case, induced by government fiscal policies) bear persistent effects upon output levels, rates of growth, and rates of innovations. In that, Keynesian policies not only have a strong impact on output volatility and unemployment, but seem to be also a necessary condition for long-run economic growth.

In fact, our results suggest that the matching or mismatching between innovative exploration of new technologies and the conditions of demand generation appear to yield two distinct "regimes" of growth (or absence thereof), also characterized by different short-run fluctuations and unemployment levels. Even when Keynesian policies allow for a sustained growth, their tuning affects the amplitude of fluctuations and the long-term levels of unemployment and output. Symmetrically, fluctuations and unemployment rates are also affected by "Schumpeterian policies", holding constant macro-demand management rules.

The rest of the paper is organized as follows. Section 2 describes the model. In Section 3 we perform empirical validation checks and in Section 4 we present results of policy exercises. Finally, Section 5 concludes and discusses future extensions.

\section{The model}

As already mentioned, our simple economy is composed of a machine-producing sector made of $F_{1}$ firms (denoted by the subscript $i$ ), a consumption-good sector made of $F_{2}$ firms (denoted by the subscript $j$ ), $L^{S}$ consumers/workers, and a public sector. Capital-good firms invest in R\&D and produce heterogenous machines. Consumption-good firms combine machine tools bought by capital-good firms and labor in order to produce a final product for consumers. The public sector levies taxes on firms' profits and pay unemployment benefits. Innovations are clearly endogenous to our economy. It is the uncertain outcome of the search efforts of the producers of capital equipment and exerts its impact throughout the economy via both the lowering of the production costs of such equipment and its diffusion in the "downstream" consumption-good sector. Before accurately describing the model, we briefly provide the timeline of events occurring in each time step.

\subsection{The timeline of events}

In any given time period $(t)$, the following microeconomic decisions take place in sequential order:

1. Machine-tool firms perform R\&D trying to discover new products and more efficient production techniques and to imitate the technology and the products of their competitors.

\footnotetext{
7 See Fagiolo et al. (2007) for a discussion; more on that in Section 3. The potential for policy exercises in ABMs is discussed in the special issue on “Agent-Based Models for Economic Policy Design” of the Journal of Economic Behavior and Organization, 2008 (vol. 67, no. 2), edited by Herbert Dawid and Giorgio Fagiolo.
} 
2. Capital-good firms advertise their machines with consumption-good producers.

3. Consumption-good firms decide how much to produce and invest. If investment is positive, consumption-good firms choose their supplier and send their orders.

4. In both industries firms hire workers according to their production plans and start producing.

5. Imperfectly competitive consumption-good market opens. The market shares of firms evolve according to their price competitiveness.

6. Entry and exit take places. In both sectors firms with near zero market shares and negative net liquid assets are eschewed from the two industries and replaced by new firms.

7. Machines ordered at the beginning of the period are delivered and become part of the capital stock at time $t+1$.

At the end of each time step, aggregate variables (e.g. GDP, investment, employment) are computed, summing over the corresponding microeconomic variables.

Let us now turn to a more detailed description of the model and of the agents' behaviors, which-to repeat-we try to keep as close as we can to what we know they actually do as distinct from what they ought to do under more perfect informational circumstances.

\subsection{The capital-good industry}

The technology of a capital-good firms is $\left(A_{i}^{\tau}, B_{i}^{\tau}\right)$, where the former coefficient stands for the labor productivity of the machine-tool manufactured by $i$ for the consumption-good industry (a rough measure of producer quality), while the latter coefficient is the labor productivity of the production technique employed by firm $i$ itself. The positive integer $\tau$ denotes the current technology vintage. Given the monetary wage $w$, the unit cost of production of capital-good firms is

$$
c_{i}(t)=\frac{w(t)}{B_{i}^{\tau}} .
$$

With a fixed mark-up $\left(\mu_{1}>0\right)$ pricing rule, ${ }^{8}$ prices $\left(p_{i}\right)$ are defined as

$$
p_{i}(t)=\left(1+\mu_{1}\right) c_{i}(t)
$$

The unit labor cost of production in the consumption-good sector associated with each machine of vintage $\tau$, produced by firm $i$ is

$$
c\left(A_{i}^{\tau}, t\right)=\frac{w(t)}{A_{i}^{\tau}}
$$

Firms in the capital-good industry "adaptively" strive to increase their market shares and their profits trying to improve their technology both via innovation and imitation. Both are costly processes: firms invest in R\&D a fraction of their past sales $\left(S_{i}\right)$ :

$$
R D_{i}(t)=v S_{i}(t-1)
$$

with $0<v<1$. R\&D expenditures are employed to hire researchers paying the market wage $w(t) .{ }^{9}$ Firms split their R\&D efforts between innovation $(I N)$ and imitation $(I M)$ according to the parameter $\xi \in[0,1]^{10}$ :

$$
\begin{aligned}
& I N_{i}(t)=\xi R D_{i}(t), \\
& I M_{i}(t)=(1-\xi) R D_{i}(t) .
\end{aligned}
$$

We model innovation as a two steps process. The first one determines whether a firm obtains or not an access to innovation-irrespectively of whether it is ultimately a success or a failure - through a draw from a Bernoulli distribution, whose parameter $\theta_{i}^{\text {in }}(t)$ is given by

$$
\theta_{i}^{i n}(t)=1-e^{-\zeta_{1} I N_{i}(t)}
$$

with $0<\zeta_{1} \leq 1$. Note that according to (4), there are some scale-related returns to R\&D investment: access to innovative discoveries is more likely if a firm puts more resources into R\&D. If a firm innovates, it may draw a new machine embodying technology $\left(A_{i}^{\text {in }}, B_{i}^{\text {in }}\right)$ according to

$$
\begin{aligned}
& A_{i}^{i n}(t)=A_{i}(t)\left(1+x_{i}^{A}(t)\right) \\
& B_{i}^{i n}(t)=B_{i}(t)\left(1+x_{i}^{B}(t)\right),
\end{aligned}
$$

\footnotetext{
${ }^{8}$ Survey data evidence summarized in Fabiani et al. (2006) show that European firms mostly set prices according to mark-up rules

9 In the following, we assume all capital-producing firms to be identical in their R\&D propensity. This is not too far from reality: R\&D intensities are largely sector specific and associated with the sector-wide nature of innovative opportunities and modes of innovative search (more in Pavitt, 1984; Dosi, 1988; Klevorick et al., 1995).

${ }^{10}$ Firms on the technological frontier, lacking anyone to imitate, obviously invest all their R\&D budget in the search for innovations.
} 
where $x_{i}^{A}$ and $x_{i}^{B}$ are two independent draws from a Beta $\left(\alpha_{1}, \beta_{1}\right)$ distribution over the support $\left[\underline{x}_{1}, \bar{x}_{1}\right]$ with $\underline{x}_{1}$ belonging to the interval $[-1,0]$ and $\bar{x}_{1}$ to $[0,1]$. Note that the notional possibilities of technological advance-i.e. technological opportunities - are captured by the support of the Beta distribution and by its shape. So, for example, with low opportunities the largest probability density falls over "failed" innovations-that is potential capital goods which are "worse" in terms of costs and performances than those already produced by the searching firm. Conversely, under a condition of rich opportunities, innovations which dominate incumbent technologies will be drawn with high probability. As we shall show below, a crucial role of "Schumpeterian" technology policies is precisely that of influencing opportunities and microcapabilities.

Alike innovation search, imitation follows a two steps procedure. The possibilities of accessing imitation come from sampling a $\operatorname{Bernoulli}\left(\theta_{i}^{i m}(t)\right)$ :

$$
\theta_{i}^{i m}(t)=1-e^{-\zeta_{2} I M_{i}(t)} \text {, }
$$

with $0<\zeta_{2} \leq 1$. Firms accessing the second stage are able to copy the technology of one of the competitors $\left(A_{i}^{i m}{ }^{i m} B_{i}\right)$. We assume that firms are more likely to imitate competitors with similar technologies and we use a Euclidean metric to compute the technological distance between every pair of firms to weight imitation probabilities.

All firms which draw a potential innovation or imitation have to put it on production or keep producing the incumbent generation of machines. Comparing the technology competing for adoption, firms choose to manufacture the machine characterized by the best tradeoff between price and efficiency. More specifically, knowing that consumption-good firms invest following a payback period routine (see Section 2.3), capital-good firms select the machine to produce according to the following rule:

$$
\min \left[p_{i}^{h}(t)+b c^{h}\left(A_{i}^{h}, t\right)\right], \quad h=\tau, i n, i m,
$$

where $b$ is a positive payback period parameter (see Eq. (10)). Once the type of machine is chosen, we capture the imperfect information pervading the market assuming that each firm sends a "brochure" with the price and the productivity of its offered machines to both its historical $\left(H C_{i}\right)$ clients and to a random sample of potential new customers $\left(N C_{i}\right)$, whose size is proportional to $H C_{i}$ (i.e., $N C_{i}(t)=\gamma H C_{i}(t)$, with $0<\gamma<1$ ).

\subsection{The consumption-good industry}

Consumption-good firms produce a homogenous goods using capital (i.e. their stock of machines) and labor under constant returns to scale. Firms plan their production $\left(Q_{j}\right)$ according to adaptive demand expectations $\left(D_{j}^{e}\right)$ :

$$
D_{j}^{e}(t)=f\left(D_{j}(t-1), D_{j}(t-2), \ldots, D_{j}(t-h)\right),
$$

where $D_{j}(t-1)$ is the demand actually faced by firm $j$ at time $t-1$ ( $h$ positive integer). ${ }^{11}$ The desired level of production $\left(Q_{j}^{d}\right)$ depends on the expected demand as well as on the desired inventories $\left(N_{j}^{d}\right)$ and the actual stock of inventories $\left(N_{j}\right)$ :

$$
Q_{j}^{d}(t)=D_{j}^{e}(t)+N_{j}^{d}(t)-N_{j}(t-1)
$$

with $N_{j}^{d}(t)=\imath D_{j}^{e}(t), l \in[0,1]$. The output of consumption-good firms is constrained by their capital stock $\left(K_{j}\right)$. If the desired capital stock $\left(K_{j}^{d}\right)$ —computed as a function of the desired level of production-is higher than the current capital stock, firms invest $\left(E I_{j}^{d}\right)$ in order to expand their production capacity ${ }^{12}$ :

$$
E I_{j}^{d}(t)=K_{j}^{d}(t)-K_{j}(t) .
$$

The capital stock of each firm is obviously composed of heterogenous vintages of machines with different productivity. We define $\Xi_{j}(t)$ as the set of all vintages of machine-tools belonging to firm $j$ at time $t$. Firms scrap machines following a payback period routine. Through that, technical change and equipment prices influence the replacement decisions of consumption-good firms. ${ }^{13}$ More specifically, firm $j$ replaces machine $A_{i}^{\tau} \in \Xi_{j}(t)$ according to its technology obsolescence as well as the price of new machines:

$$
R S_{j}(t)=\left\{A_{i}^{\tau} \in \Xi_{j}(t): \frac{p^{*}(t)}{c\left(A_{i, \tau}, t\right)-C^{*}(t)} \leq b\right\},
$$

where $p^{*}$ and $c^{*}$ are the price and unit cost of production upon the new machines. Firms compute their replacement investment summing up the number of old machine-tools satisfying Eq. (10). ${ }^{14}$

\footnotetext{
${ }^{11}$ For maximum simplicity, here we use the rule $D_{j}^{e}(t)=D_{j}(t-1)$. In Dosi et al. (2006a) we check the robustness of the simulation results employing more sophisticated expectation-formation rules. We found that increasing the computational capabilities of firms does not significantly change either the average growth rates or the stability of the economy. These properties still hold in the model presented here.

${ }^{12}$ We assume that in any give period firm capital growth rates cannot exceed a fixed maximum threshold consistent with the maximum capital growth rates found in the empirical literature on firm investment patterns (e.g. Doms and Dunne, 1998).

13 This in line with a large body of empirical analyses (e.g. Feldstein and Foot, 1971; Eisner, 1972; Goolsbee, 1998) showing that replacement investment is typically not proportional to the capital stock.

${ }^{14}$ Moreover, they also scrap the machines older than $\eta$ periods (with $\eta$ being a positive integer).
} 
Consumption-good firms choose their capital-good supplier comparing the price and productivity of the currently manufactured machine-tools they are aware of. As we mentioned above (cf. Section 2.2) the capital-good market is systematically characterized by imperfect information. This implies that consumption-good firms compare "brochures" describing the characteristics of machines only from a subset of equipment suppliers. Firms then choose the machines with the lowest price and unit cost of production (i.e., $p_{i}(t)+b c\left(A_{i}^{\tau}, t\right)$ ) and send their orders to the correspondingly machine manufacturer. Machine production is a time-consuming process: capital-good firms deliver the ordered machine-tools at the end of the period. ${ }^{15}$ Gross investment of each firm $\left(I_{j}\right)$ is the sum of expansion and replacement investment. Pooling the investment of all consumption-good firms one gets aggregate investment $(I)$.

Consumption-good firms have to finance their investments as well as their production, as they advance worker wages. In line with a growing number of theoretical and empirical papers (e.g. Stiglitz and Weiss, 1992; Greenwald and Stiglitz, 1993a; Hubbard, 1998) we assume imperfect capital markets. This implies that the financial structure of firms matters (external funds are more expensive than internal ones) and firms may be credit rationed. More specifically, consumptiongood firms finance production using their stock of liquid assets $\left(N W_{j}\right)$. If liquid assets do not fully cover production costs, firms borrow the remaining part paying an interest rate $r$ up to a maximum debt/sales ratio of $\Lambda$. Only firms that are not production-rationed can try to fulfill their investment plans employing their residual stock of liquid assets first and then their residual borrowing capacity. ${ }^{16}$

Given their current stock of machines, consumption-good firms compute average productivity $\left(\pi_{j}\right)$ and unit cost of production $\left(c_{j}\right)$. Prices are set applying a variable markup $\left(\mu_{j}\right)$ on unit costs of production:

$$
p_{j}(t)=\left(1+\mu_{j}(t)\right) c_{j}(t)
$$

Markup variations are regulated by the evolution of firm market shares $\left(f_{j}\right)^{17}$ :

$$
\mu_{j}(t)=\mu_{j}(t-1)\left(1+v \frac{f_{j}(t-1)-f_{j}(t-2)}{f_{j}(t-2)}\right),
$$

with $0 \leq v \leq 1$

The consumption-good market too is characterized by imperfect information (antecedents in the same spirits are Phelps and Winter, 1970; Klemperer, 1987; Farrel and Shapiro, 1988; see also the empirical literature on consumers' imperfect price knowledge surveyed in Rotemberg, 2008). This implies that consumers do not instantaneously switch to products made by more competitive firms. However, prices are clearly one of the key determinants of firms' competitiveness $\left(E_{j}\right)$. The other component is the level of unfilled demand $\left(l_{j}\right)$ inherited from the previous period:

$$
E_{j}(t)=-\omega_{1} p_{j}(t)-\omega_{2} l_{j}(t)
$$

where $\omega_{1,2}$ are positive parameters. ${ }^{18}$ Weighting the competitiveness of each consumption-good firm by its past market share $\left(f_{j}\right)$, one can compute the average competitiveness of the consumption-good sector:

$$
\bar{E}(t)=\sum_{j=1}^{F_{2}} E_{j}(t) f_{j}(t-1)
$$

Such variable represents also a moving selection criterion driving, other things being equal, expansion, contraction and extinction within the population of firms. We parsimoniously model this market setup letting firm market shares evolve according to a "quasi" replicator dynamics (for antecedents in the evolutionary camp cf. Silverberg et al., 1988; Metcalfe, 1994a):

$$
f_{j}(t)=f_{j}(t-1)\left(1+\chi \frac{E_{j}(t)-\bar{E}(t)}{\bar{E}(t)}\right),
$$

with $\chi>0 .^{19}$

The profits $\left(\Pi_{j}\right)$ of each consumption-good firm reads

$$
\Pi_{j}(t)=S_{j}(t)-c_{j}(t) Q_{j}(t)-r D e b_{j}(t)
$$

\footnotetext{
${ }^{15}$ Among the empirical literature investigating the presence of gestation-lag effects in firm investment expenditures see e.g. Del Boca et al. (2008).

${ }^{16}$ If investment plans cannot be fully realized, firms give priority to capital stock expansion, as compared to the substitution of old machines.

17 This is close to the spirit of "customer market" models originated by the seminal work of Phelps and Winter (1970). See also Klemperer (1995) for a survey and the exploration of some important macro-implications by Greenwald and Stiglitz (2003).

${ }^{18}$ Recall that consumption-good firms fix production according to their demand expectations, which may differ from actual demand. If the firm produced too much, the inventories pile up, whereas if its production is lower than demand plus inventories, its competitiveness is accordingly reduced.

19 Strictly speaking, a canonic replicator dynamics evolves on the unit simplex with all entities having positive shares. Eq. (13) allows shares to become virtually negative. In that case, the firm is declared dead and market shares are accordingly re-calculated. This is what we mean by a "quasireplicator" dynamics. Note that an advantage of such formulation is that it determines at the same time changes in market shares and extinction events.
} 
where $S_{j}(t)=p_{j}(t) D_{j}(t)$ and Deb denotes the stock of debt. The investment choices of each firm and its profits determine the evolution of its stock of liquid assets $\left(N W_{j}\right)$ :

$$
N W_{j}(t)=N W_{j}(t-1)+\Pi_{j}(t)-C I_{j}(t),
$$

where $c I_{j}$ is the amount of internal funds employed by firm $j$ to finance investment.

\subsection{Schumpeterian exit and entry dynamics}

At the end of each period we let firms with (quasi) zero market shares or negative net assets die and we allow a new breed of firms to enter the markets. We keep the number of firms fixed, hence any dead firm is replaced by a new one.

In line with the empirical literature on firm entry (Caves, 1998; Bartelsman et al., 2005), we assume that entrants are on average smaller than incumbents, with the stock of capital of new consumption-good firms and the stock of liquid assets of entrants in both sectors being a fraction of the average stocks of the incumbents. ${ }^{20}$ Concerning the technology of entrants, new consumption-good firms select amongst the newest vintages of machines, according to the "brochure mechanism" described above. The process- and product-related knowledge of new capital-good firms is drawn from a Beta distribution, whose shape and support is shifted and "twisted" according to whether entrants enjoy an advantage or a disadvantage vis-à-vis incumbents. ${ }^{21}$ In fact, the distribution of opportunities for entrants vs. incumbents is a crucial characteristics of different sectoral technological regimes and plays a role somewhat akin to the distance from the technological frontier of entrants discussed in Aghion and Howitt (2007).

\subsection{The labor market}

The labor market is certainly not Walrasian: real-wage does not clear the market and involuntary unemployment as well as labor rationing are the rules rather than the exceptions. The aggregate labor demand $\left(L^{D}\right)$ is computed summing up the labor demand of capital- and consumption-good firms. The aggregate supply $\left(L^{S}\right)$ is exogenous and inelastic. Hence aggregate employment $(L)$ is the minimum between $L^{D}$ and $L^{S}$.

The wage rate is determined by institutional and market factors, with both indexation mechanisms upon consumption prices and average productivity, on the one hand, and, adjustments to unemployment rates, on the others:

$$
w(t)=w(t-1)+\left(1+\psi_{1} \frac{\Delta \overline{A B}(t)}{\overline{A B}(t-1)}+\psi_{2} \frac{\Delta c p i(t)}{c p i(t-1)}+\psi_{3} \frac{\Delta U(t)}{U(t-1)}\right),
$$

where $\overline{A B}$ is the average labor productivity, cpi is the consumer price index, and $U$ is the unemployment rate. Various institutional regimes for the labor market can be designed changing the system parameters $\psi_{1,2,3}{ }^{22}$

\subsection{Consumption, taxes, and public expenditures}

An otherwise black boxed public sector levies taxes on firm profits and worker wages or on profits only and pays to unemployed workers a subsidy $\left(w^{u}\right)$, that is a fraction of the current market wage (i.e., $w^{u}(t)=\varphi w(t)$, with $\varphi \in(0,1)$ ). In fact, taxes and subsidies are the fiscal leverages that contribute to the aggregate demand management regimes (we shall explore this issue in more detail below). Note that a "zero tax, zero subsidy" scenario is our benchmark for a pure Schumpeterian regime of institutional governance.

Aggregate consumption $(C)$ is computed by summing up over the income of both employed and unemployed workers:

$$
C(t)=w(t) L^{D}(t)+w^{u}\left(L^{S}-L^{D}(t)\right)
$$

The model satisfies the standard national account identities: the sum of value added of capital- and consumption goods firms $(Y)$ equals their aggregate production since in our simplified economy there are no intermediate goods, and that in turn coincides with the sum of aggregate consumption, investment and change in inventories $(\Delta N)$ :

$$
\sum_{i=1}^{F_{1}} Q_{i}(t)+\sum_{j=1}^{F_{2}} Q_{j}(t)=Y(t) \equiv C(t)+I(t)+\Delta N(t) .
$$

The dynamics generated at the micro-level by decisions of a multiplicity of heterogenous, adaptive agents and by their interaction mechanisms is the explicit microfoundation of the dynamics for all aggregate variables of interest (e.g. output, investment, employment, etc.). However, as the model amply demonstrates, the aggregate properties of the economy do

\footnotetext{
20 The stock of capital of a new consumption-good firm is obtained multiplying the average stock of capital of the incumbents by a random draw from a Uniform distribution with support $\left[\phi_{1}, \phi_{2}\right], 0<\phi_{1},<\phi_{2} \leq 1$. In the same manner, the stock of liquid assets of an entrant is computed multiplying the average stock of liquid assets of the incumbents of the sector by a random variable distributed according to a Uniform with support [ $\left.\phi_{3}, \phi_{4}\right], 0<\phi_{3},<\phi_{4} \leq 1$.

${ }^{21}$ More precisely, the technology of capital-good firms is obtained applying a coefficient extracted from a Beta( $\left(\alpha_{2}, \beta_{2}\right)$ distribution to the endogenously evolving technology frontier $\left(A^{\max }(t), B^{\max }(t)\right)$, where $A^{\max }(t)$ and $B^{\max }(t)$ are the best technology available to incumbents.

${ }^{22}$ For more detailed modelizations of the labor market in a evolutionary/ACE framework see e.g. Tesfatsion (2000), Fagiolo et al. (2004), and Neugart (2008).
} 
Table 1

Benchmark parameters.

\begin{tabular}{|c|c|c|}
\hline Description & Symbol & Value \\
\hline Number of firms in capital-good industry & $F_{1}$ & 50 \\
\hline Number of firms in consumption-good industry & $F_{2}$ & 200 \\
\hline R\&D investment propensity & $v$ & 0.04 \\
\hline R\&D allocation to innovative search & $\xi$ & 0.50 \\
\hline Firm search capabilities parameters & $\zeta_{1,2}$ & 0.30 \\
\hline Beta distribution parameters (innovation process) & $\left(\alpha_{1}, \beta_{1}\right)$ & $(3,3)$ \\
\hline Beta distribution support (innovation process) & {$\left[\underline{x}_{1}, \bar{x}_{1}\right]$} & {$[-0.15,0.15]$} \\
\hline New-customer sample parameter & $\gamma$ & 0.50 \\
\hline Capital-good firm mark-up rule & $\mu_{1}$ & 0.04 \\
\hline Desired inventories & $l$ & 0.10 \\
\hline Payback period & $b$ & 3 \\
\hline "Physical" scrapping age & $\eta$ & 20 \\
\hline Mark-up coefficient & $v$ & 0.04 \\
\hline Competitiveness weights & $\omega_{1,2}$ & 1 \\
\hline Replicator dynamics coefficient & $\chi$ & 1 \\
\hline Maximum debt/sales ratio & $\Lambda$ & 2 \\
\hline Interest rate & $r$ & 0.01 \\
\hline $\begin{array}{l}\text { Uniform distribution supports } \\
\text { (consumption-good entrant capital) }\end{array}$ & {$\left[\phi_{1}, \phi_{2}\right]$} & {$[0.10,0.90]$} \\
\hline $\begin{array}{l}\text { Uniform distribution supports } \\
\text { (entrant stock of liquid assets) }\end{array}$ & {$\left[\phi_{3}, \phi_{4}\right]$} & {$[0.10,0.90]$} \\
\hline $\begin{array}{l}\text { Beta distribution parameters } \\
\text { (capital-good entrants technology) }\end{array}$ & $\left(\alpha_{2}, \beta_{2}\right)$ & $(2,4)$ \\
\hline Wage setting $\triangle \overline{A B}$ weight & $\psi_{1}$ & 1 \\
\hline Wage setting $\Delta c p i$ weight & $\psi_{2}$ & 0 \\
\hline Wage setting $\Delta U$ weight & $\psi_{3}$ & 0 \\
\hline Tax rate & $\operatorname{tr}$ & 0.10 \\
\hline Unemployment subsidy rate & $\varphi$ & 0.40 \\
\hline
\end{tabular}

not bears any apparent isomorphism with those microadjustment rules outlined above. And a fundamental consequence is also that any "representative agent" compression of microheterogeneity is likely to offer a distorted account of both what agents do and of the collective outcomes of their actions-indeed, well in tune with the arguments of Kirman (1992) and Solow (2008).

\section{Empirical validation}

The foregoing model does not allow for analytical, closed-form solutions. This general ABM distinctive feature stems from the non-linearities present in agent decision rules and their interaction patterns, and it forces us to run computer simulations to analyze the properties of the stochastic processes governing the coevolution of micro- and macrovariables. $^{23}$ In what follows, we therefore perform extensive Monte-Carlo analyses to wash away across-simulation variability. Consequently, all results below refer to across-run averages over 100 replications and their standard-error bands. ${ }^{24}$

Let us start from a sort of "benchmark" setup for which the model is empirically validated, i.e. it is studied in its ability to replicate a wide spectrum of microeconomic and macroeconomic stylized facts. Initial conditions and parameters of the benchmark setup are presented in Table 1.

As it should be clear from the forgoing presentation of the model, it embodies both a Schumpeterian engine and a Keynesian one. The former rests in the generation of innovations by an ensemble of equipment producers which expensively search and endogenously differentiate in the technology they are able to master. The Keynesian engine has two parts: a direct one_through fiscal policies_and an indirect one-via investment decisions and workers' consumption. Hence, the benchmark model appropriately embodies all such Schumpeterian and Keynesian features.

Next we tune so to speak "up" and "down" the key policy variables (e.g. tax rates and unemployment benefits) and we experiment with different conditions affecting the access to and exploitation of new technological opportunities (e.g. the patent regime, anti-trust policies).

\footnotetext{
${ }^{23}$ Some methodological issues concerning the exploration of the properties of evolutionary/ACE models are discussed in e.g. Lane (1993), Pyka and Fagiolo (2007), Fagiolo et al. (2007), and Fagiolo and Roventini (forthcoming).

${ }^{24}$ Preliminary exercises confirm that, for the majority of statistics under study, Monte-Carlo distributions are sufficiently symmetric and unimodal to justify the use of across-run averages as meaningful synthetic indicators.
} 
Let us first explore the ability of the model to reproduce the major stylized facts regarding both the properties of macroeconomic aggregates and the underlying distribution of micro characteristics (more on both in the direct antecedents to this model: cf. Dosi et al., 2006a, 2008).

Growth and fluctuations. The model robustly generates endogenous self-sustained growth patterns characterized by the presence of persistent fluctuations (cf. Fig. 1). At business cycle frequencies, bandpass-filtered output, investment and consumption series (Bpf, cf. Baxter and King, 1999) display the familiar "roller-coaster" dynamics (see Fig. 2) observed in

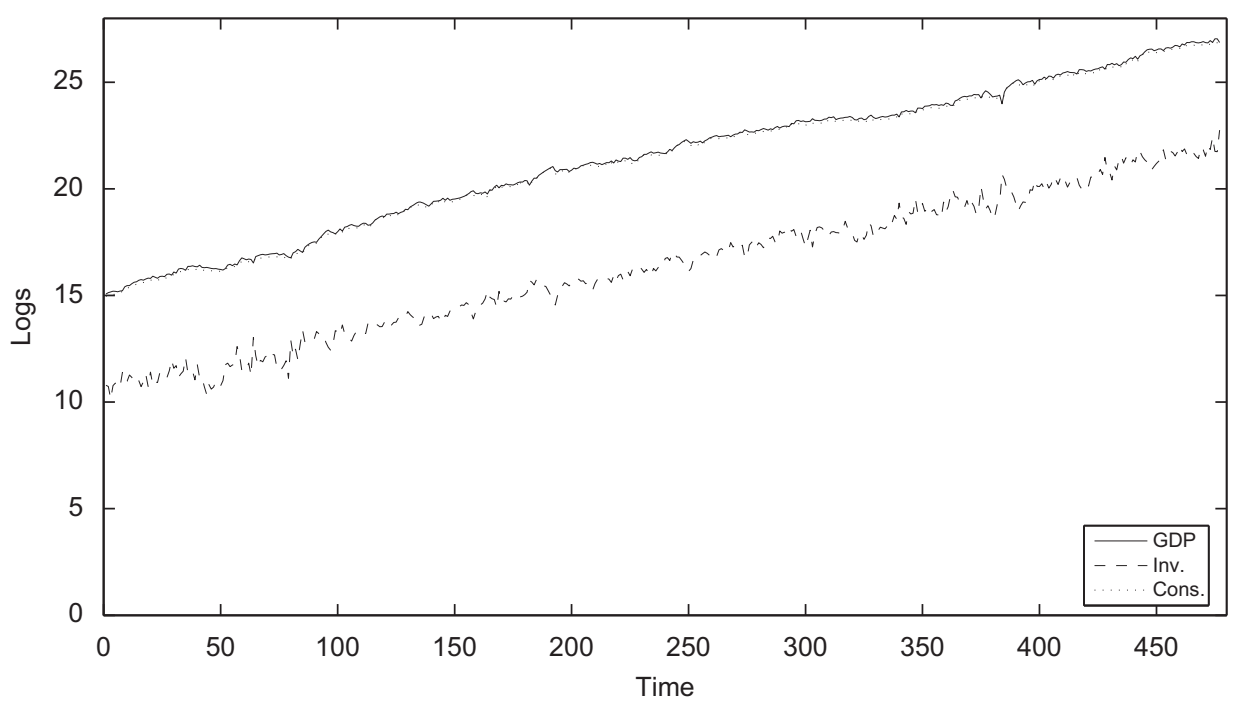

Fig. 1. Level of output, investment, and consumption (logs).

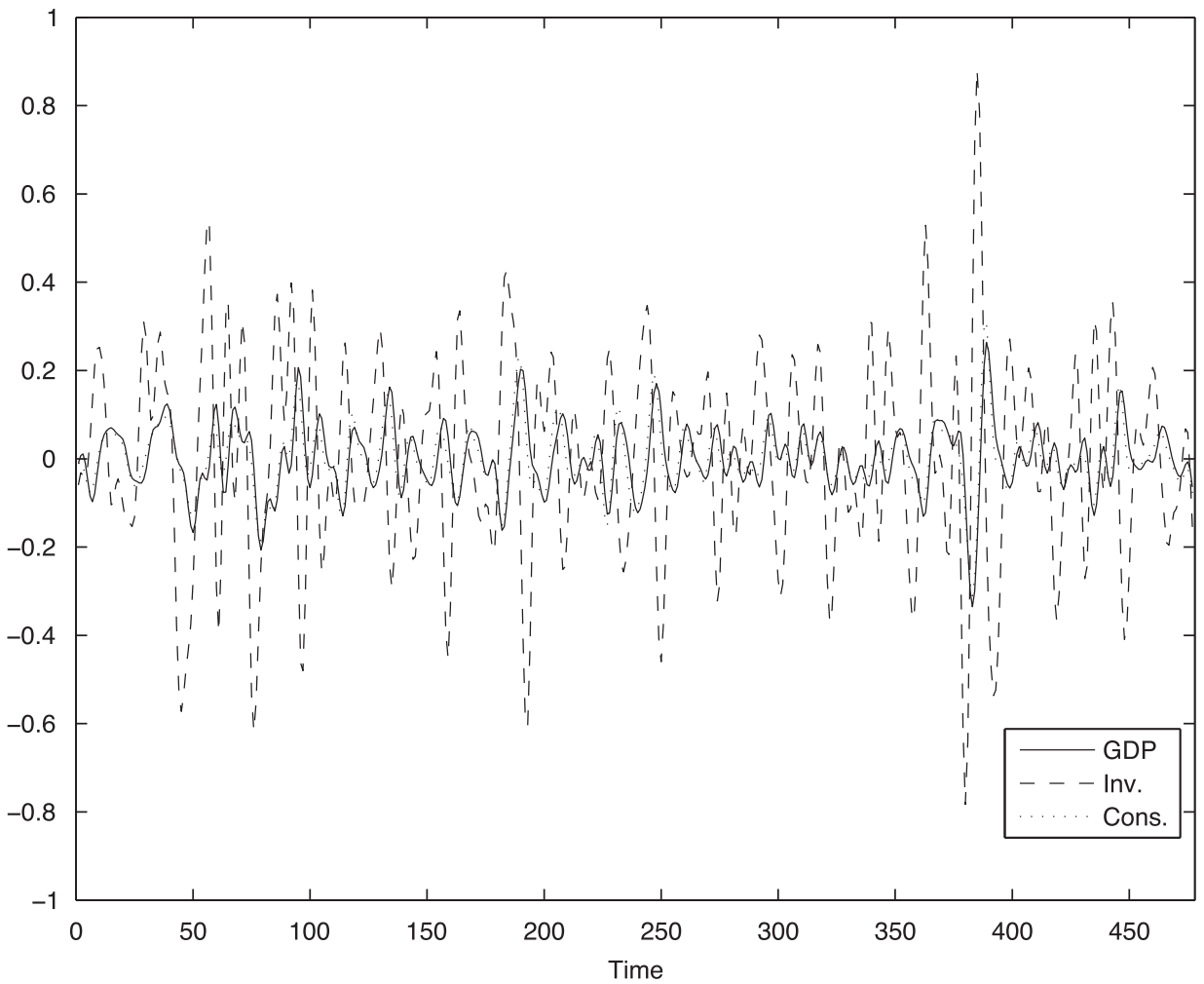

Fig. 2. Bandpass-filtered output, investment, and consumption. 
Table 2

Output, investment, and consumption statistics.

\begin{tabular}{|c|c|c|c|}
\hline & Output & Consumption & Investment \\
\hline Avg. growth rate & $\begin{array}{c}0.0254 \\
(0.0002)\end{array}$ & $\begin{array}{c}0.0252 \\
(0.0002)\end{array}$ & $\begin{array}{c}0.0275 \\
(0.0004)\end{array}$ \\
\hline Dickey-Fuller test (logs) & $\begin{array}{c}6.7714 \\
(0.0684)\end{array}$ & $\begin{array}{c}9.4807 \\
(0.0957)\end{array}$ & $\begin{array}{c}0.2106 \\
(0.0633)\end{array}$ \\
\hline Dickey-Fuller test (Bpf) & $\begin{array}{r}-6.2564^{*} \\
(0.0409)\end{array}$ & $\begin{array}{r}-5.8910^{*} \\
(0.0447)\end{array}$ & $\begin{array}{r}-6.8640^{*} \\
(0.0905)\end{array}$ \\
\hline Std. dev. (Bpf) & $\begin{array}{c}0.0809 \\
(0.0007)\end{array}$ & $\begin{array}{c}0.0679 \\
(0.0005)\end{array}$ & $\begin{array}{c}0.4685 \\
(0.0266)\end{array}$ \\
\hline Rel. std. dev. (output) & 1 & 0.8389 & 5.7880 \\
\hline
\end{tabular}

Bpf: bandpass-filtered $(6,32,12)$ series. Monte-Carlo simulation standard errors in parentheses. $\left({ }^{*}\right)$ : Significant at $5 \%$.

Table 3

Correlation structure.

\begin{tabular}{|c|c|c|c|c|c|c|c|c|c|}
\hline \multirow[t]{2}{*}{ Series (Bpf) } & \multicolumn{9}{|c|}{ Output (Bpf) } \\
\hline & $t-4$ & $t-3$ & $t-2$ & $t-1$ & $t$ & $t+1$ & $t+2$ & $t+3$ & $t+4$ \\
\hline Output & $\begin{array}{r}-0.1022 \\
(0.0090)\end{array}$ & $\begin{array}{c}0.1769 \\
(0.0080)\end{array}$ & $\begin{array}{c}0.5478 \\
(0.0048)\end{array}$ & $\begin{array}{c}0.8704 \\
(0.0014)\end{array}$ & $\begin{array}{r}1 \\
(0)\end{array}$ & $\begin{array}{c}0.8704 \\
(0.0014)\end{array}$ & $\begin{array}{c}0.5478 \\
(0.0048)\end{array}$ & $\begin{array}{c}0.1769 \\
(0.0080)\end{array}$ & $\begin{array}{r}-0.1022 \\
(0.0090)\end{array}$ \\
\hline Consumption & $\begin{array}{c}-0.1206 \\
(0.0123)\end{array}$ & $\begin{array}{c}0.0980 \\
(0.0129)\end{array}$ & $\begin{array}{c}0.4256 \\
(0.0106)\end{array}$ & $\begin{array}{c}0.7563 \\
(0.0062)\end{array}$ & $\begin{array}{c}0.9527 \\
(0.0017)\end{array}$ & $\begin{array}{c}0.9248 \\
(0.0018)\end{array}$ & $\begin{array}{c}0.6848 \\
(0.0038)\end{array}$ & $\begin{array}{c}0.3394 \\
(0.0058)\end{array}$ & $\begin{array}{c}0.0250 \\
(0.0072)\end{array}$ \\
\hline Investment & $\begin{array}{c}-0.2638 \\
(0.0102)\end{array}$ & $\begin{array}{c}-0.3123 \\
(0.0137)\end{array}$ & $\begin{array}{r}-0.2646 \\
(0.0182)\end{array}$ & $\begin{array}{c}-0.0864 \\
(0.0210)\end{array}$ & $\begin{array}{c}0.1844 \\
(0.0206)\end{array}$ & $\begin{array}{c}0.4473 \\
(0.0175)\end{array}$ & $\begin{array}{c}0.5950 \\
(0.0139)\end{array}$ & $\begin{array}{c}0.5757 \\
(0.0123)\end{array}$ & $\begin{array}{c}0.4206 \\
(0.0129)\end{array}$ \\
\hline Net investment & $\begin{array}{r}-0.0838 \\
(0.0122)\end{array}$ & $\begin{array}{c}0.0392 \\
(0.0167)\end{array}$ & $\begin{array}{c}0.2195 \\
(0.0216)\end{array}$ & $\begin{array}{c}0.4010 \\
(0.0235)\end{array}$ & $\begin{array}{c}0.5114 \\
(0.0211)\end{array}$ & $\begin{array}{c}0.5037 \\
(0.0153)\end{array}$ & $\begin{array}{c}0.3850 \\
(0.0103)\end{array}$ & $\begin{array}{c}0.2105 \\
(0.0112)\end{array}$ & $\begin{array}{c}0.0494 \\
(0.0138)\end{array}$ \\
\hline Ch. in invent. & $\begin{array}{c}0.0072 \\
(0.0081)\end{array}$ & $\begin{array}{c}0.1184 \\
(0.0070)\end{array}$ & $\begin{array}{c}0.2349 \\
(0.0060)\end{array}$ & $\begin{array}{c}0.2948 \\
(0.0072)\end{array}$ & $\begin{array}{c}0.2573 \\
(0.0090)\end{array}$ & $\begin{array}{c}0.1331 \\
(0.0098)\end{array}$ & $\begin{array}{r}-0.0199 \\
(0.0097)\end{array}$ & $\begin{array}{c}-0.1319 \\
(0.0085)\end{array}$ & $\begin{array}{r}-0.1640 \\
(0.0067)\end{array}$ \\
\hline Employment & $\begin{array}{c}-0.3240 \\
(0.0087)\end{array}$ & $\begin{array}{c}-0.1901 \\
(0.0123)\end{array}$ & $\begin{array}{c}0.0796 \\
(0.0151)\end{array}$ & $\begin{array}{c}0.4083 \\
(0.0160)\end{array}$ & $\begin{array}{c}0.6692 \\
(0.0149)\end{array}$ & $\begin{array}{c}0.7559 \\
(0.0120)\end{array}$ & $\begin{array}{c}0.6451 \\
(0.0084)\end{array}$ & $\begin{array}{c}0.4067 \\
(0.0069)\end{array}$ & $\begin{array}{c}0.1555 \\
(0.0082)\end{array}$ \\
\hline Unempl. rate & $\begin{array}{c}0.3357 \\
(0.0083)\end{array}$ & $\begin{array}{c}0.2084 \\
(0.0118)\end{array}$ & $\begin{array}{c}-0.0596 \\
(0.0147)\end{array}$ & $\begin{array}{r}-0.3923 \\
(0.0158)\end{array}$ & $\begin{array}{c}-0.6607 \\
(0.0148)\end{array}$ & $\begin{array}{c}-0.7550 \\
(0.0120)\end{array}$ & $\begin{array}{r}-0.6489 \\
(0.0084)\end{array}$ & $\begin{array}{c}-0.4112 \\
(0.0070)\end{array}$ & $\begin{array}{r}-0.1583 \\
(0.0082)\end{array}$ \\
\hline Productivity & $\begin{array}{c}0.1180 \\
(0.0097)\end{array}$ & $\begin{array}{c}0.3084 \\
(0.0088)\end{array}$ & $\begin{array}{c}0.5316 \\
(0.0092)\end{array}$ & $\begin{array}{c}0.7108 \\
(0.0093)\end{array}$ & $\begin{array}{c}0.7672 \\
(0.0076)\end{array}$ & $\begin{array}{c}0.6656 \\
(0.0067)\end{array}$ & $\begin{array}{c}0.4378 \\
(0.0097)\end{array}$ & $\begin{array}{c}0.1664 \\
(0.0126)\end{array}$ & $\begin{array}{r}-0.0609 \\
(0.0128)\end{array}$ \\
\hline Price & $\begin{array}{c}0.2558 \\
(0.0167)\end{array}$ & $\begin{array}{c}0.3181 \\
(0.0218)\end{array}$ & $\begin{array}{c}0.2702 \\
(0.0235)\end{array}$ & $\begin{array}{c}0.0916 \\
(0.0216)\end{array}$ & $\begin{array}{c}-0.1645 \\
(0.0198)\end{array}$ & $\begin{array}{r}-0.3950 \\
(0.0212)\end{array}$ & $\begin{array}{r}-0.5067 \\
(0.0225)\end{array}$ & $\begin{array}{c}-0.4688 \\
(0.0210)\end{array}$ & $\begin{array}{r}-0.3249 \\
(0.0176)\end{array}$ \\
\hline Inflation & $\begin{array}{r}-0.1070 \\
(0.0151)\end{array}$ & $\begin{array}{c}0.0841 \\
(0.0135)\end{array}$ & $\begin{array}{c}0.3110 \\
(0.0175)\end{array}$ & $\begin{array}{c}0.4456 \\
(0.0226)\end{array}$ & $\begin{array}{c}0.4021 \\
(0.0228)\end{array}$ & $\begin{array}{c}0.1966 \\
(0.0188)\end{array}$ & $\begin{array}{r}-0.0628 \\
(0.0154)\end{array}$ & $\begin{array}{c}-0.2478 \\
(0.0146)\end{array}$ & $\begin{array}{r}-0.2900 \\
(0.0131)\end{array}$ \\
\hline Mark-up & $\begin{array}{c}0.2183 \\
(0.0118)\end{array}$ & $\begin{array}{c}0.1599 \\
(0.0088)\end{array}$ & $\begin{array}{c}0.0411 \\
(0.0128)\end{array}$ & $\begin{array}{c}-0.0988 \\
(0.0184)\end{array}$ & $\begin{array}{c}-0.2040 \\
(0.0213)\end{array}$ & $\begin{array}{c}-0.2361 \\
(0.0206)\end{array}$ & $\begin{array}{r}-0.1968 \\
(0.0174)\end{array}$ & $\begin{array}{r}-0.1226 \\
(0.0135)\end{array}$ & $\begin{array}{r}-0.0580 \\
(0.0107)\end{array}$ \\
\hline
\end{tabular}

Bpf: bandpass-filtered $(6,32,12)$ series. Monte-Carlo simulation standard errors in parentheses.

real data (e.g. Stock and Watson, 1999; Napoletano et al., 2006). Moreover, in tune with the empirical evidence, both consumption and investment appear to be procyclical variables with the latter series being also more volatile than GDP.

Output, consumption and investment display strictly positive average growth rates ${ }^{25}$ (cf. Table 2) and, according to Dickey-Fuller tests, they seem to exhibit a unit root. After detrending the series with a bandpass filter, we compute standard deviations and cross-correlations between output and the other series. In line with the empirical literature on business cycles (cf. Stock and Watson, 1999), also in our model investment is more volatile than output, whereas consumption is less volatile; consumption, investment, change in inventories, and employment are procyclical; unemployment is countercyclical (cf. Table 3 ). ${ }^{26}$

\footnotetext{
${ }^{25}$ The average growth rate of variable $X$ (e.g. GDP) is simply defined as$$
\overline{G R}_{X}=\frac{\log X(T)-\log X(0)}{T+1},
$$

where $T=600$ is the econometric sample size. This value for $T$ is a quite conservative choice, as the first iterative moments of growth statistics converge to a stable behavior well before such a time horizon. This means that the model reaches a relatively (meta) stable behavior quite soon after simulations start. Our experiment show that choosing larger values for $T$ does not alter the main economic implications of the paper.

${ }^{26}$ Consumption and net investment are also coincident variables matching yet another empirical regularity on business cycles. Changes in inventories are instead slightly lagging. 
Table 4

Growth-rate distributions, estimation of exponential-power parameters.

\begin{tabular}{lllrrr}
\hline Series & $b$ & Std. dev. & \multicolumn{1}{c}{$a$} & Std. dev. & \multicolumn{1}{c}{ Std. dev. } \\
\hline Capital-good & 0.5285 & 0.0024 & 0.4410 & 0.0189 & -0.0089 \\
Consumption-good & 0.4249 & 0.0051 & 0.0289 & 0.0037 & 0.0225 \\
Output & 1.4673 & 0.0122 & 0.0775 & 0.0004 & -0.0027 \\
\hline
\end{tabular}

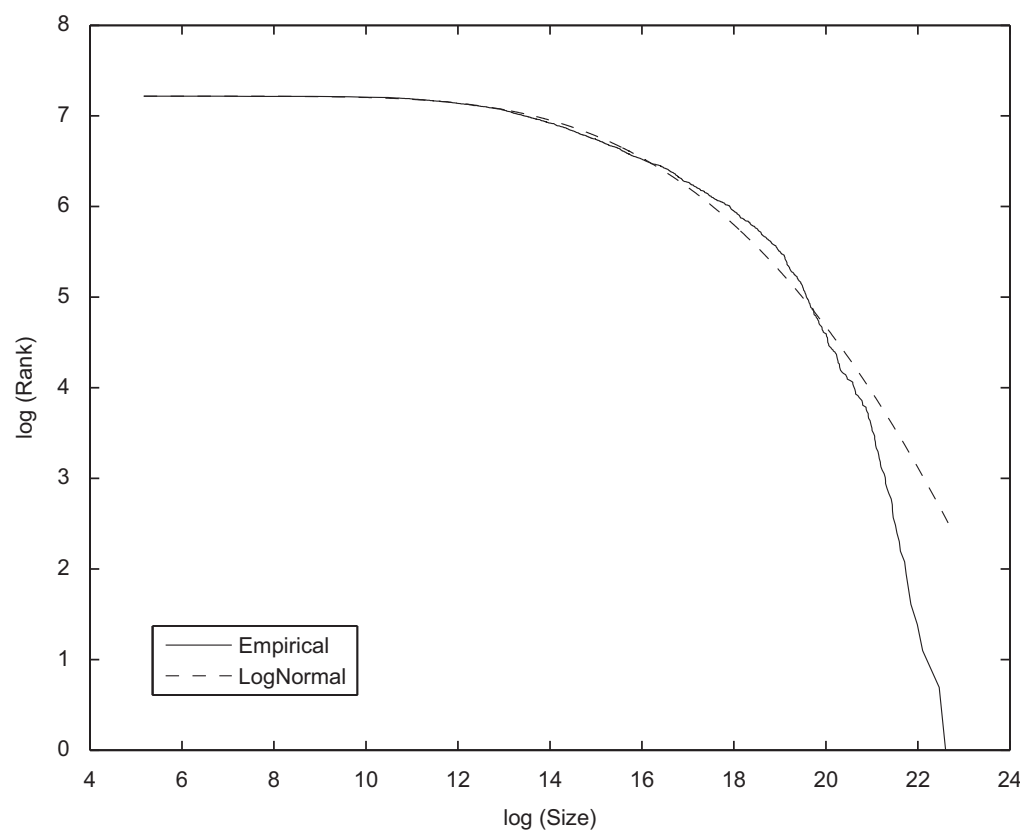

Fig. 3. Pooled (year-standardized) capital-good firm sales distributions. Log rank vs. log size plots.

The model is also able to match the business-cycle properties concerning productivity, price, inflation and markups (see Table 3): productivity is procyclical, prices are countercyclical and leading; inflation is procyclical and lagging; markups are countercyclical (for the empirics and discussion cf. Stock and Watson, 1999; Rotemberg and Woodford, 1999).

Finally, the aggregate growth rates of output display fat-tailed distributions well in tune with the empirical evidence (cf. Table 4; see Castaldi and Dosi, 2009; Fagiolo et al., 2008). Informally, this means that both in our model and in reality relatively big "spurs of growth" and recessions occur much more frequently than it would be predicted on the grounds of normally distributed shocks (see also below on firm growth patterns).

Distributions of microeconomics characteristics. Together with the ability of the model to account for a rich ensemble of macro-phenomena, how does it fare in its matching with the evidence on the ubiquitous microheterogeneity? Let us consider the regularities concerning firm-size and growth-rate distributions, firm-productivity dynamics and firminvestment patterns which are generated by the model.

To begin with, well in tune with the empirical evidence (Dosi, 2007), rank-size plots and normality tests suggest that cross-section firm (log) size distributions are skewed and not log-normal (see Figs. 3 and 4 and Table 5). Moreover, the estimation of the shape parameters of exponential-power (Subbotin) distributions ${ }^{27}$ shows that pooled firm growth-rate distributions are "tent-shaped" with tails fatter than the Gaussian benchmark (see Table 4 and, for a comparison with the empirical evidence and some interpretation, see Bottazzi and Secchi, 2003, 2006).

Turning to firm productivity, again in line with the empirical evidence (cf. the surveys in Bartelsman and Doms, 2000; Dosi, 2007), firms strikingly differ in terms of labor productivity (cf. standard deviations of labor productivity across firms

${ }^{27}$ We estimate a distribution of the form:

$$
f(x ; b, a, m)=\frac{1}{2 a b^{1 / b} \Gamma\left(1+\frac{1}{b}\right)} e^{-(1 / b)(x-m) /\left.a\right|^{b}} .
$$

In a Subbotin distribution one parameter $-b$, in Table 4 - governs the fatness of the tails. The Normal distribution is recovered when $b=2$, the fatter Laplace distribution when $b=1$. 


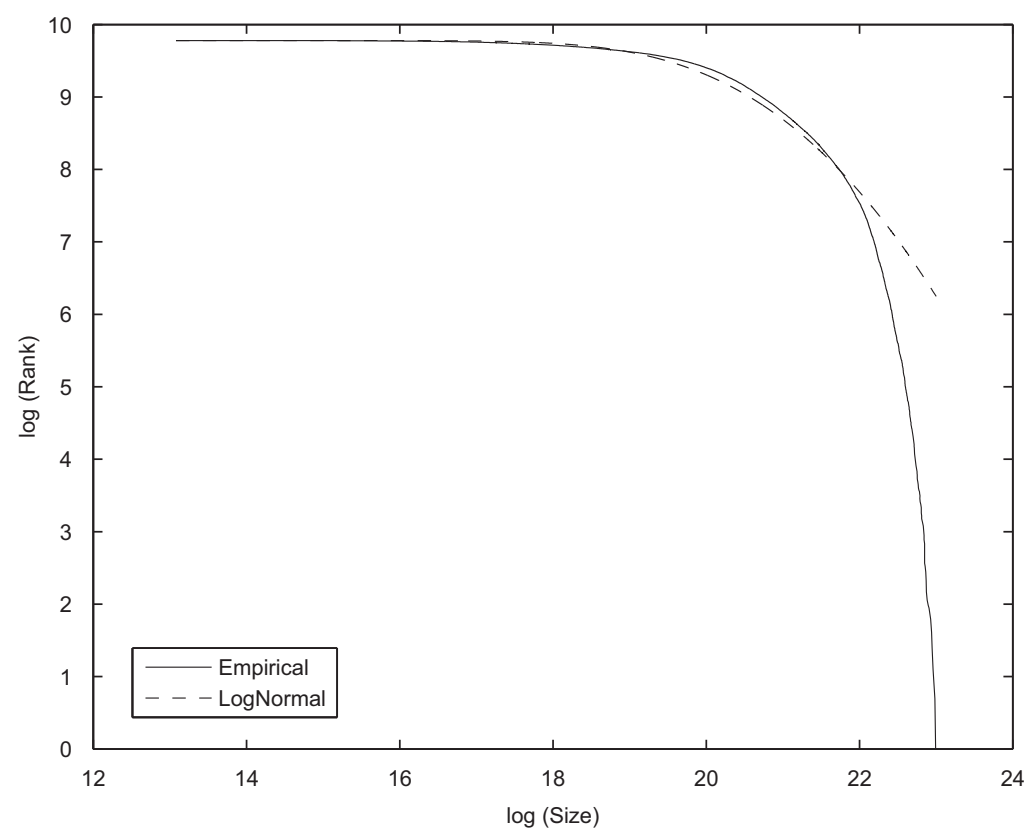

Fig. 4. Pooled (year-standardized) consumption-good firm sales distributions. Log rank vs. log size plots.

Table 5

Log-size distributions, normality tests.

\begin{tabular}{|c|c|c|c|c|c|c|}
\hline \multirow[t]{2}{*}{ Industry } & \multicolumn{2}{|l|}{ Jarque-Bera } & \multicolumn{2}{|c|}{ Lilliefors } & \multicolumn{2}{|c|}{ Anderson-Darling } \\
\hline & Stat. & $p$-Value & Stat. & $p$-Value & Stat. & $p$-Value \\
\hline Capital-good & 20.7982 & 0 & 0.0464 & 0 & 4.4282 & 0 \\
\hline Consumption-good & 3129.7817 & 0 & 0.0670 & 0 & 191.0805 & 0 \\
\hline
\end{tabular}

plotted in Fig. 5), productivity differentials persist over time (cf. firm productivity autocorrelations reported in Table 6) ${ }^{28}$ and productivity growth rates are Laplace distributed (i.e. again, the distribution exhibits fat tails).

Finally, we have analyzed firm investment patterns. The model is indeed able to generate as an emergent property investment lumpiness (Doms and Dunne, 1998; Caballero, 1999). Indeed, in each time step, consumption-good firms with "near" zero investment coexist with firms experiencing investment spikes (see Fig. 6 and relate it to Gourio and Kashyap, 2007).

\section{Policy experiments: tuning Schumpeterian and Keynesian regimes}

The model, we have seen, is empirically quite robust in that it accounts, together, for a large number of empirical regularities. It certainly passes a much higher "testing hurdle", as Solow (2008) puts it, than simply reproducing "a few of the low moments of observed time series: ratios of variances or correlation coefficients, for instance" (p. 245) as most current models content themselves with. Encouraged by that empirical performance of the model, let us experiment with different structural conditions (e.g. concerning the nature of innovative opportunities) and policy regimes, and study their impact on output growth rates, volatility and rates of unemployment. ${ }^{29}$

\footnotetext{
${ }^{28}$ In the last 200 periods of the simulations, we consider the autocorrelation of firms that survived for at least 20 periods and we compute the industry average.

${ }^{29}$ Interestingly, most other statistical regularities concerning the structure of the economy (e.g. size distributions, fatness of firms growth rates, etc.) appear to hold across an ample parameter range, under positive technological progress, even when policies undergo the changes we study in the following.
} 

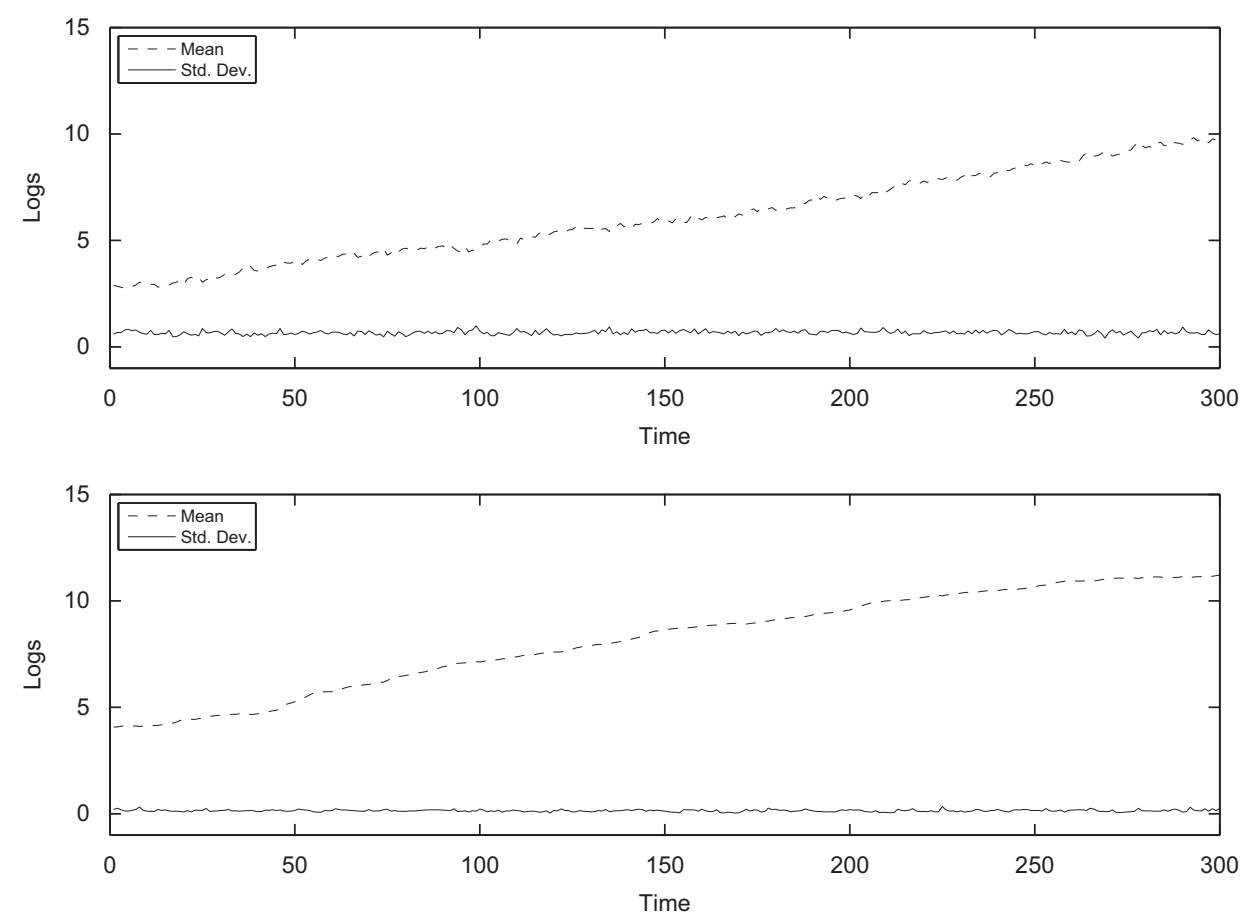

Fig. 5. Firms' productivity moments (logs). First panel: capital-good firms. Second panel: consumption-good firms.

Table 6

Average autocorrelation of productivity.

\begin{tabular}{lcc}
\hline Industry & $t-1$ & $t-2$ \\
\hline Capital-good & 0.5433 & 0.3700 \\
& $(0.1821)$ & $(0.2140)$ \\
Consumption-good & 0.5974 & 0.3465 \\
& $(0.2407)$ & $(0.2535)$ \\
\hline
\end{tabular}

Standard deviations in parentheses.
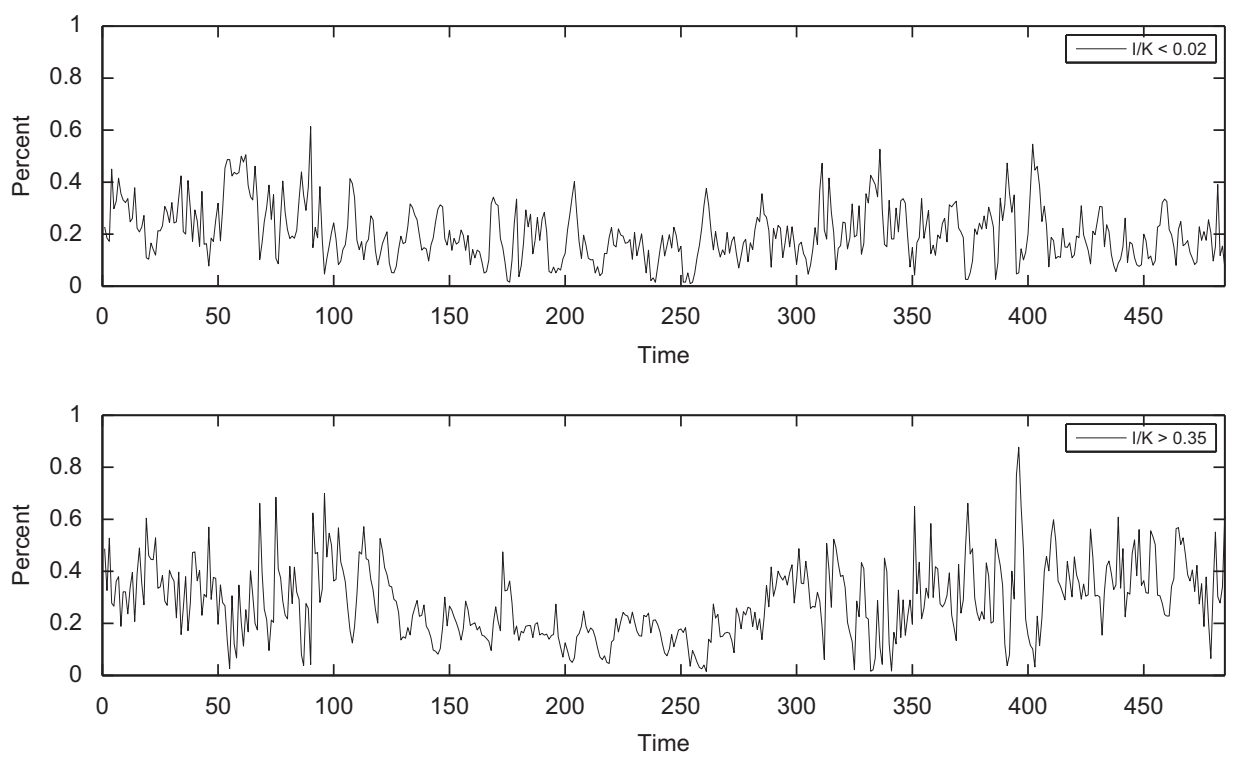

Fig. 6. Investment lumpiness. First panel: share of firms with (near) zero investment; second panel: share of firms with investment spikes. 
Table 7

Schumpeterian regime technological and industrial policy experiments.

\begin{tabular}{|c|c|c|c|c|}
\hline Experiment & Description & Avg. GDP growth rate & GDP std. dev. (Bpf) & Avg. unemployment \\
\hline 0 & Benchmark scenario & $\begin{array}{c}0.0254 \\
(0.0002)\end{array}$ & $\begin{array}{c}0.0809 \\
(0.0007)\end{array}$ & $\begin{array}{c}0.1072 \\
(0.0050)\end{array}$ \\
\hline 1.1 & Low technological opportunities & $\begin{array}{c}0.0195 \\
(0.0001)\end{array}$ & $\begin{array}{c}0.0794 \\
(0.0008)\end{array}$ & $\begin{array}{c}0.1357 \\
(0.0050)\end{array}$ \\
\hline 1.2 & High technological opportunities & $\begin{array}{c}0.0315 \\
(0.0002)\end{array}$ & $\begin{array}{c}0.0828 \\
(0.0007)\end{array}$ & $\begin{array}{c}0.1025 \\
(0.0051)\end{array}$ \\
\hline 2.1 & Low search capabilities & $\begin{array}{c}0.0231 \\
(0.0002)\end{array}$ & $\begin{array}{c}0.0825 \\
(0.0008)\end{array}$ & $\begin{array}{c}0.1176 \\
(0.0059)\end{array}$ \\
\hline 2.2 & High search capabilities & $\begin{array}{c}0.0268 \\
(0.0002)\end{array}$ & $\begin{array}{c}0.0775 \\
(0.0008)\end{array}$ & $\begin{array}{c}0.1031 \\
(0.0048)\end{array}$ \\
\hline 3.1 & No imitation & $\begin{array}{c}0.0254 \\
(0.0002)\end{array}$ & $\begin{array}{c}0.0693 \\
(0.0008)\end{array}$ & $\begin{array}{c}0.1049 \\
(0.0059)\end{array}$ \\
\hline 3.2 & Patent (length only) & $\begin{array}{c}0.0242 \\
(0.0002)\end{array}$ & $\begin{array}{c}0.0761 \\
(0.0008)\end{array}$ & $\begin{array}{c}0.1132 \\
(0.0060)\end{array}$ \\
\hline 3.3 & Patent (breadth, too) & $\begin{array}{c}0.0163 \\
(0.0001)\end{array}$ & $\begin{array}{c}0.0631 \\
(0.0007)\end{array}$ & $\begin{array}{c}0.1329 \\
(0.0067)\end{array}$ \\
\hline 4.1 & Low entrant expected productivity & $\begin{array}{c}0.0183 \\
(0.0003)\end{array}$ & $\begin{array}{c}0.0798 \\
(0.0012)\end{array}$ & $\begin{array}{c}0.1402 \\
(0.0084)\end{array}$ \\
\hline 4.2 & Higher entrant expected productivity & $\begin{array}{c}0.0376 \\
(0.0002)\end{array}$ & $\begin{array}{c}0.0697 \\
(0.0006)\end{array}$ & $\begin{array}{c}0.0853 \\
(0.0047)\end{array}$ \\
\hline 5.1 & Weak antitrust & $\begin{array}{c}0.0265 \\
(0.0002)\end{array}$ & $\begin{array}{c}0.0698 \\
(0.0006)\end{array}$ & $\begin{array}{c}0.1036 \\
(0.0043)\end{array}$ \\
\hline 5.2 & Strong antitrust & $\begin{array}{c}0.0273 \\
(0.0001)\end{array}$ & $\begin{array}{c}0.0508 \\
(0.0005)\end{array}$ & $\begin{array}{c}0.0837 \\
(0.0036)\end{array}$ \\
\hline 6 & Schumpeter-only, no fiscal policy & $\begin{array}{c}0.0110 \\
(0.0018)\end{array}$ & $\begin{array}{c}1.5511 \\
(0.0427)\end{array}$ & $\begin{array}{c}0.7855 \\
(0.0274)\end{array}$ \\
\hline
\end{tabular}

Bpf: bandpass-filtered $(6,32,12)$ series. Monte-Carlo simulations standard errors in parentheses.

\subsection{Alternative innovation and competition regimes}

Consider first the Schumpeterian side of the economy, holding the "Keynesian engine" constant as compared with the benchmark scenario ${ }^{30}$ : Table 7 summarizes the results. Let us start by turning off endogenous technological opportunities. In this case, the model collapses onto a barebone 2-sector Solow (1956) model in steady state, with fixed coefficients and zero growth (absent demographic changes).

Opportunities and search capabilities. What happens if one changes the opportunities of technological innovation and the ability to search for them? Experiment 1 (Table 7) explores such a case. As compared to the benchmark, we shift rightward and leftward the mass of the Beta distribution governing new technological draws (i.e. the parameters $\alpha_{1}$ and $\beta_{1}$, cf. Section 2.2). Note that the support of the distribution remains unchanged, so that one could informally state that the notional possibilities of drift in the technological frontier remain unchanged, too. However, the "pool" of opportunities agents actually face get either richer or more rarefied. We find that higher opportunities have a positive impact on the long-term rate of growth, reduce average unemployment and slightly increase GDP volatility (a mark of Schumpeterian "gales of creative destruction"?).

Somewhat similarly, higher search capabilities approximated by the possibilities of accessing "innovations"-no matter if failed or successful ones-(cf. the $\zeta_{1,2}$ parameters in Eqs. (4) and (5)) positively influence the rates of growth and lower unemployment. Together, business cycle fluctuations are dampened possibly because a population of "more competent" firms entails lower degrees of technological asymmetries across them and indeed also lower degrees of "creative destruction". See experiment 2, Table 7.

Note that such role of innovative opportunities and search capabilities is in principle equivalent to that black-boxed into the more aggregate notions of "human capital" (Nelson and Phelps, 1966; Benhabib and Spiegel, 1994) and of "appropriate institutions" (Acemoglu et al., 2006). ${ }^{31}$

Appropriability conditions. In many current models with a (neo) Schumpeterian engine, appropriability conditions play a key role via their assumptions on the forward looking rationality of the agent(s) investing into uncertain innovative search: the degrees of monopoly appropriation of the economic benefits from successful search parametrize the equilibrium

\footnotetext{
30 The full list of parameters under different policy scenarios is available from the authors on request.

${ }^{31}$ In fact, given the increasing availability of microdata one can start thinking of disaggregated empirical proxies for our variables. The issue is, however, well beyond the scope of this work.
} 
Table 8

Keynesian regime fiscal policy experiments.

\begin{tabular}{|c|c|c|c|c|}
\hline Tax rate & $\begin{array}{l}\text { Unemployment subsidy } \\
\text { (in \% of wages) }\end{array}$ & Avg. GDP growth rate & GDP std. dev. (Bpf) & Avg. unemployment \\
\hline 0 & 0 & $\begin{array}{c}0.0035 \\
(0.0012)\end{array}$ & $\begin{array}{c}1.5865 \\
(0.0319)\end{array}$ & $\begin{array}{c}0.8868 \\
(0.0201)\end{array}$ \\
\hline 0.05 & 0.20 & $\begin{array}{c}0.0254 \\
(0.0002)\end{array}$ & $\begin{array}{c}0.1539 \\
(0.0025)\end{array}$ & $\begin{array}{c}0.1952 \\
(0.0086)\end{array}$ \\
\hline 0.10 & 0.40 & $\begin{array}{c}0.0252 \\
(0.0002)\end{array}$ & $\begin{array}{c}0.0809 \\
(0.0007)\end{array}$ & $\begin{array}{c}0.1072 \\
(0.0050)\end{array}$ \\
\hline 0.15 & 0.60 & $\begin{array}{c}0.0251 \\
(0.0002)\end{array}$ & $\begin{array}{c}0.0630 \\
(0.0005)\end{array}$ & $\begin{array}{c}0.0846 \\
(0.0034)\end{array}$ \\
\hline 0.20 & 0.80 & $\begin{array}{c}0.0254 \\
(0.0002)\end{array}$ & $\begin{array}{c}0.0584 \\
(0.0006)\end{array}$ & $\begin{array}{c}0.0602 \\
(0.0027)\end{array}$ \\
\hline 0.25 & 1 & $\begin{array}{c}0.0252 \\
(0.0002)\end{array}$ & $\begin{array}{c}0.0564 \\
(0.0005)\end{array}$ & $\begin{array}{c}0.0551 \\
(0.0023)\end{array}$ \\
\hline
\end{tabular}

Bpf: bandpass-filtered $(6,32,12)$ series. Monte-Carlo simulations standard errors in parentheses.

relation between investment in $R \& D$ and rates of innovation. In this model, we took a much more behavioral route and assumed a fixed propensity to invest in R\&D_-again, quite in tune with the evidence displaying relatively sticky and sectoral specific propensities. Granted that, how do changes in appropriability conditions affect aggregate dynamics?

We first studied an extreme condition (albeit rather common in the theoretical literature), turning off the possibility of imitation, and assuming that all R\&D is invested in innovative search. Interestingly (and admittedly to the surprise of the authors) we basically find no differences vis-à-vis the benchmark scenario: compare experiment 3.1 with experiment 0 , Table 7 .

Let us then try to mimic the effect of a patent system. Under a "length only" patent scenario, the innovative technology cannot be imitated for a given number of periods determined by the patent length (cf. experiment 3.2, Table 7). Such patenting possibility is detrimental to long-run growth and also augments the average rate of unemployment. The negative aggregate impact of the patent system is reinforced if each firm cannot innovate in some neighborhood of the other firms' technologies-i.e. in the presence of a patent breadth: see experiment 3.3, Table $7 .^{32}$

Entry and competition policies. Important dimensions of distinct Schumpeterian regimes of innovation regard, first, the advantages/disadvantages that entrants face vis-à-vis incumbents and, second, the market conditions placing economic rewards and punishments upon heterogenous competitors.

The first theme cuts across the evolutionary and neo-Schumpeterian literature and sometimes is dramatized as a "Schumpeterian Mark I" vs. a "Schumpeterian Mark II" scenarios, meaning systematic innovative advantages for entrepreneurial entrants vs. cumulative advantages of incumbents (cf. Malerba and Orsenigo, 1995; Dosi et al., 1995). In our model, technological entry barriers (or advantages) are captured by the probability distribution over the "technological draws" of entrants. Again, we hold constant the support over which the economy (i.e. every firm thereof) may draw innovative advances, conditional on the technology at any $t$. In this case we do it for the sake of consistency: results, even more so, apply if different regimes are also allowed to entail different probability supports. Let us first tune the Beta distribution parameters $\alpha_{2}$ and $\beta_{2}$ (cf. Section 2.4). Our results are broadly in line with the evidence discussed in Aghion and Howitt (2007): other things being equal, the easiness of entry and competence of entrants bears a positive impact upon long-term growth, mitigates business cycles fluctuations and reduces average unemployment. See experiments 4.1 and 4.2, Table 7. However, the ceteris paribus condition is equally important: the same aggregate growth patterns can be proved to be equally guaranteed by competent cumulative learning of incumbents (see, above, the exercises on search capabilities).

What about competitive conditions? We introduce antitrust policies by forbidding capital-good firms to exceed a given market share (75\% in experiment 5.1 and 50\% in experiment 5.2, Table 7): the outcome is a lower unemployment rate, smaller business cycle fluctuations and also higher GDP growth (on this point see also Fogel et al., 2008). Note that such a property have little to do with any static "welfare gains"-which our model does not explicitly contemplates-but rather with the multiplicity of producers, and thus of innovative search avenues, which antitrust policies safeguard. ${ }^{33}$

\footnotetext{
32 On purpose, we did not introduce any feedback between changes in IPR regimes and propensities to search. As discussed in Dosi et al. (2006b), such a link is absent in all historical evidence on the effects of changes in patenting regimes and both investment in R\&D and innovative intensity.

33 The thrust of our results on policies affecting entry, competition, and variety preservation are indeed broadly in tune with the advocacy for "evolutionary technology policies" in Metcalfe (1994b), while it runs against the so-called "Schumpeterian hypothesis" according to which degrees of industrial concentration should be conducive to higher rates of innovation.
} 

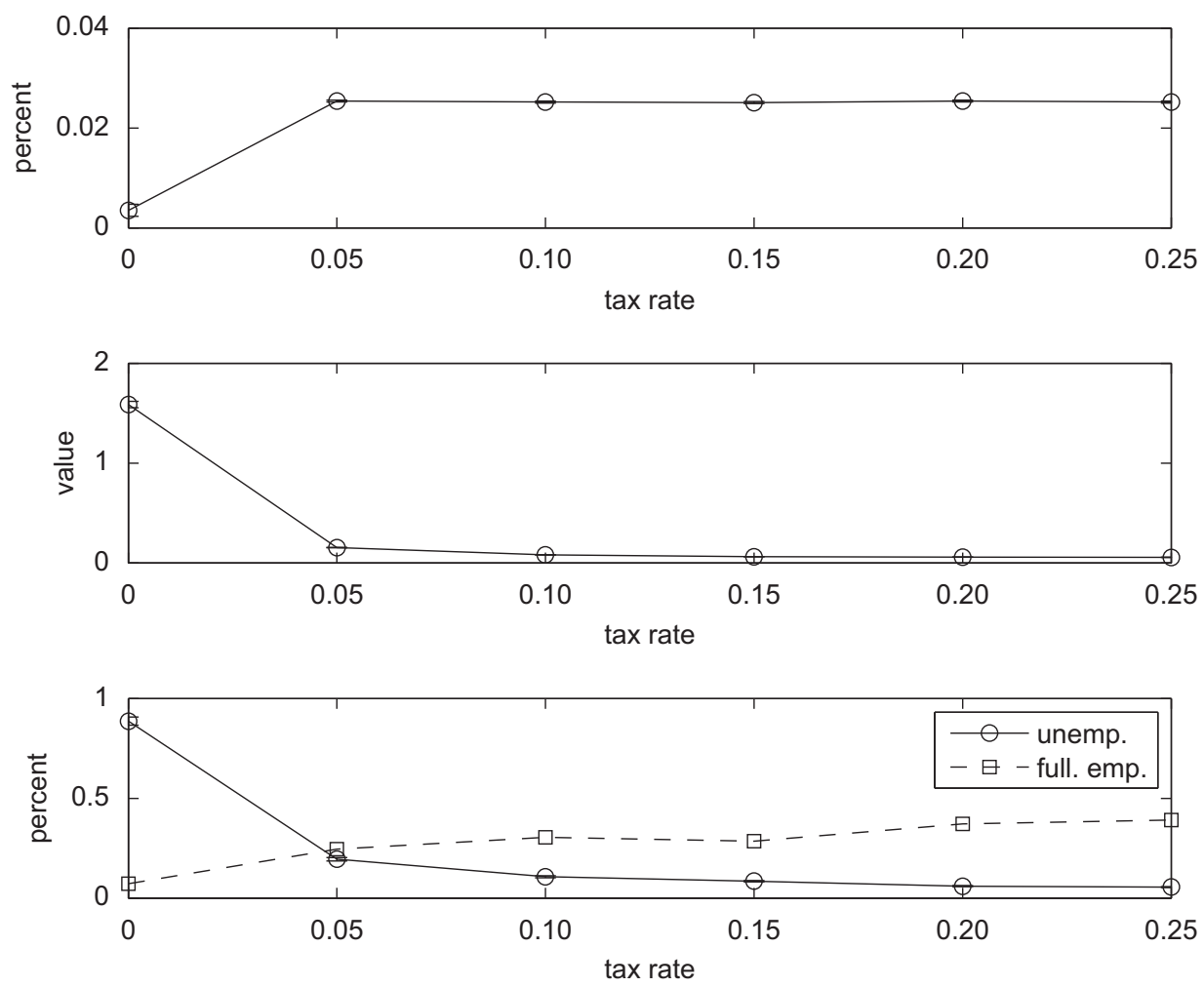

Fig. 7. Fiscal policy experiments. First panel: average output growth rate. Second panel: bandpass-filtered output standard deviation. Third panel: average unemployment rate (unemp.) and full-employment frequency (full emp.). In such policy experiments, the unemployment subsidy rate ( $\varphi$ ) is four times the tax rate.

\subsection{The Keynesian engine, or is Schumpeter enough?}

So far we have explored the effects of different means of "Schumpeterian" policies and organizational setups over the long term (i.e. over the rate of growth of the economy) and on unemployment rates and output volatilities. We did find significant effects both on the long and short terms. However, to repeat, such results are conditional on a "Keynesian machine" well in place. What happens if we switch that off? Remarkably, the system dramatically slows down in terms of rates of growth, unemployment shoots up to utterly unrealistic levels and volatility increases. Note that it does so even if we consider a regime with simultaneously "high opportunities" and "high search capabilities" (experiment 6, Table 7). So for example, for the same richness of innovative opportunities, the long-term rate of growth falls to around a third (compare experiments 6 and 1.2).

Let us further explore the role of fiscal policies over both the short- and long-term properties of the economy. Consider the experiments presented in Table 8. We begin with eschewing the public sector from the economy by setting both tax rate and unemployment benefits to zero while keeping the benchmark Schumpeterian characteristics in place. In such a scenario, the economy experiments wilder fluctuations and higher unemployment rates in the short-run, but also an output growth in the long-run not far from nil. Countercyclical Keynesian policies, as in the common wisdom, act indeed like a parachute during recessions, sustaining consumption and, indirectly, investment on the demand side. However, they also bear long-term effects on the supply side: in particular on the rates of growth of productivity and output. Such a vicious feedback loop goes from low output to low investment in R\&D, low rates of innovation (cf. Eq. (3)) similar to that pointed out by Stiglitz (1994). ${ }^{34}$ In fact, in the latter as well as in our model, the system may be "trapped" into a low growth trajectories which cannot be unlocked from by a "Schumpeterian jumpstart". Indeed, as we have seen above (experiment 6 , Table 7) Schumpeterian policies alone are not able to sustain high growth patterns and, even less so, mild business cycle fluctuations and low unemployment.

Let us then allow for Keynesian demand macro-management policies and repeatedly increase both the tax and the unemployment benefit rates. Tuning up fiscal demand management does delock the economy from the "bad" trajectory

\footnotetext{
${ }^{34}$ On the negative links between macroeconomic volatility, R\&D investment, and long-run economic growth in presence of financial market imperfections, see also Aghion et al. (2008, 2010).
} 
Table 9

Robustness of simulation results to alternative labor-market institutional regimes.

\begin{tabular}{|c|c|c|c|c|c|c|c|c|c|c|c|c|c|}
\hline \multicolumn{3}{|c|}{ Parameters } & \multirow{2}{*}{$\begin{array}{l}\text { Avg. GDP } \\
\text { growth rate }\end{array}$} & \multirow{2}{*}{$\begin{array}{l}\text { Avg. } \\
\text { unemployment }\end{array}$} & \multirow{2}{*}{$\begin{array}{l}\text { GDP std. } \\
\text { dev. (bpf) }\end{array}$} & \multicolumn{2}{|c|}{ Rel. std. dev. } & \multicolumn{3}{|c|}{ Cons. Corr. } & \multicolumn{3}{|c|}{ Net Inv. Corr. } \\
\hline$\psi_{1}$ & $\psi_{2}$ & $\psi_{3}$ & & & & Cons. & Inv. & $t-1$ & $t$ & $t+1$ & $t-1$ & $t$ & $t+1$ \\
\hline 1 & 0 & 0 & $\begin{array}{c}0.0252 \\
(0.0002)\end{array}$ & $\begin{array}{c}0.1072 \\
(0.0050)\end{array}$ & $\begin{array}{c}0.0809 \\
(0.0007)\end{array}$ & 0.84 & 5.79 & 0.76 & 0.95 & 0.92 & 0.40 & 0.51 & 0.50 \\
\hline 1 & 0.75 & 0 & $\begin{array}{c}0.0249 \\
(0.0002)\end{array}$ & $\begin{array}{c}0.1167 \\
(0.0059)\end{array}$ & $\begin{array}{c}0.0766 \\
(0.0063)\end{array}$ & 0.82 & 6.83 & 0.79 & 0.96 & 0.91 & 0.49 & 0.57 & 0.52 \\
\hline 1 & 0 & -0.90 & $\begin{array}{c}0.0251 \\
(0.0002)\end{array}$ & $\begin{array}{c}0.1207 \\
(0.0049)\end{array}$ & $\begin{array}{c}0.0761 \\
(0.0062)\end{array}$ & 0.81 & 6.57 & 0.80 & 0.96 & 0.91 & 0.54 & 0.61 & 0.54 \\
\hline 1 & 0.75 & -0.90 & $\begin{array}{c}0.0246 \\
(0.0002)\end{array}$ & $\begin{array}{c}0.1155 \\
(0.0056)\end{array}$ & $\begin{array}{c}0.0743 \\
(0.0061)\end{array}$ & 0.82 & 5.87 & 0.80 & 0.96 & 0.91 & 0.53 & 0.62 & 0.56 \\
\hline
\end{tabular}

Bpf: bandpass-filtered $(6,32,12)$ series. Monte-Carlo simulations standard errors in parentheses.

Table 10

Robustness of policy experiments to alternative labor-market institutional regimes.

\begin{tabular}{|c|c|c|c|c|c|c|}
\hline \multicolumn{3}{|c|}{ Parameters } & \multirow[t]{2}{*}{ Experiment } & \multirow[t]{2}{*}{ Avg. GDP growth rate } & \multirow[t]{2}{*}{ GDP std. dev. (bpf) } & \multirow[t]{2}{*}{ Avg. unemployment } \\
\hline$\psi_{1}$ & $\psi_{2}$ & $\psi_{3}$ & & & & \\
\hline \multirow[t]{7}{*}{1} & 0.75 & 0 & 1.1 & $0.0198(0.0002)$ & $0.0776(0.0062)$ & $0.1384(0.0051)$ \\
\hline & & & 1.2 & $0.0319(0.0002)$ & $0.0769(0.0065)$ & $0.0847(0.0053)$ \\
\hline & & & 3.1 & $0.0250(0.0002)$ & $0.0729(0.0064)$ & $0.1051(0.0060)$ \\
\hline & & & 3.3 & $0.0164(0.0002)$ & $0.0592(0.0019)$ & $0.1374(0.0072)$ \\
\hline & & & 6 & $0.0033(0.0014)$ & $1.2743(0.0285)$ & $0.8836(0.0222)$ \\
\hline & & & $\operatorname{tax}=0, \phi=0$ & $-0.0008(0.0009)$ & $1.2694(0.0244)$ & $0.9495(0.0153)$ \\
\hline & & & $\operatorname{tax}=0.2, \phi=0.8$ & $0.0253(0.0002)$ & $0.0561(0.0046)$ & $0.0599(0.0029)$ \\
\hline \multirow[t]{7}{*}{1} & 0 & -0.9 & 1.1 & $0.0196(0.0002)$ & $0.0743(0.0059)$ & $0.1341(0.0050)$ \\
\hline & & & 1.2 & $0.0313(0.0002)$ & $0.0737(0.0062)$ & $0.0987(0.0063)$ \\
\hline & & & 3.1 & $0.0252(0.0002)$ & $0.0627(0.0053)$ & $0.1025(0.0062)$ \\
\hline & & & 3.3 & $0.0165(0.0002)$ & $0.0627(0.0053)$ & $0.1260(0.0072)$ \\
\hline & & & 6 & $0.0134(0.0018)$ & $1.6084(0.0899)$ & $0.7627(0.0254)$ \\
\hline & & & $\operatorname{tax}=0, \phi=0$ & $0.0032(0.0012)$ & $1.5863(0.0890)$ & $0.8857(0.0197)$ \\
\hline & & & $\operatorname{tax}=0.2, \phi=0.8$ & $0.0249(0.0002)$ & $0.0547(0.0046)$ & $0.0673(0.0030)$ \\
\hline \multirow[t]{7}{*}{1} & 0.75 & -0.9 & 1.1 & $0.0193(0.0002)$ & $0.0740(0.0059)$ & $0.1454(0.0062)$ \\
\hline & & & 1.2 & $0.0312(0.0002)$ & $0.0742(0.0063)$ & $0.0993(0.0053)$ \\
\hline & & & 3.1 & $0.0251(0.0002)$ & $0.0638(0.0053)$ & $0.1100(0.0062)$ \\
\hline & & & 3.3 & $0.0165(0.0002)$ & $0.0593(0.0047)$ & $0.1366(0.0071)$ \\
\hline & & & 6 & $0.0050(0.0016)$ & $1.2703(0.0561)$ & $0.8760(0.0265)$ \\
\hline & & & $\operatorname{tax}=0, \phi=0$ & $0.0001(0.0010)$ & $1.2236(0.0292)$ & $0.9322(0.0197)$ \\
\hline & & & $\operatorname{tax}=0.2, \phi=0.8$ & $0.0246(0.0002)$ & $0.0539(0.0047)$ & $0.0631(0.0031)$ \\
\hline
\end{tabular}

Bpf: bandpass-filtered $(6,32,12)$ series. Monte-Carlo simulations standard errors in parentheses.

and brings it to the "good" (high growth) one, which also our benchmark scenario happens to belong (cf. Table 8 and Fig. 7). If one further increases the size of fiscal measures, average output growth rates do not change as compared to the benchmark scenario, but output volatility and unemployment significantly fall, and the economy spends more time in full employment (cf. again Table 8 and Fig. 7). ${ }^{35}$

Finally, we check the robustness of Keynesian properties of the system to alternative institutional regimes governing the labor market captured by the parameters affecting the wage rate (cf. Eq. (14)). In particular, we allow wages to move as a (negative) function of the unemployment rate. Under these "classical" circumstances, wages may fall during recessions, inducing price cuts, which in turn may increase output, supposedly weakening the case for Keynesian fiscal policies. In fact, the simulation exercises presented in Table 9 suggest that, other things being equal, the dynamics of the systems are largely independent of how wages are determined. Moreover, the impact of different policy measures_including fiscal policies-does not seem to substantially change under different labor-market institutional regimes (cf. Table 10). This supports both our previous results about the importance of the "Keynesian engine" as a necessary ingredient of sustained

\footnotetext{
${ }^{35}$ On the long-run growth-enhancing effects of countercyclical macroeconomic policies, see the empirical evidence provided by Aghion and Marinescu (2007).
} 
long-run growth and Keynes (1936) own insights about the irrelevance at best of wage cuts in order to reduce unemployment.

\section{Concluding remarks}

In this work we have studied the properties of an agent-based model that robustly reproduces a wide ensemble of macro-stylized facts and distributions of micro characteristics.

The model entails the explicit account of search and investment decisions by populations of firms that are heterogeneous in the technologies which they master and, possibly, in their decision rules. Aggregate macro properties are emergent from the thread of interactions among economic agents, without any ex ante consistency requirements amongst their expectations and their actions. In that sense, the model may be considered an exercise in general disequilibrium analysis. Firms in the model endogenously generate new technologies_embodied in new types of "machines"-via expensive and mistake-ridden processes of search. Inventions then diffuse via the adoption decisions of machine users. Hence, agents generate micro technological shocks and, together, micro demand shocks which propagate through the economy.

In this respect, an important feature of the model is that it bridges Schumpeterian theories of technology-driven economic growth with Keynesian theories of demand generation.

A central question that we address in the work is whether the "Schumpeterian engine" by itself is able to maintain the economy on a high-growth/near full-employment path. Broadly speaking, the answer is negative. Such an endogenous innovation engine is able to do that only in the presence of a "Keynesian" demand-generating engine, which in the present model takes the form of public fiscal policies.

Our results also throw deep doubts on the traditional dichotomy between variables impacting the long-run (typically, technology-related changes) and variables with a short-term effect (traditional demand-related variables). On the contrary, technological innovations appear to exert their effects at all frequencies. Conversely, Keynesian demandmanagement policies do not only contribute to reduce output volatility and unemployment rates, but also for a large parameter region, they affect also long-run growth rates insofar as they contribute to "delock" the economy from the stagnant growth trajectory which is indeed one of the possible emergent meta-stable states.

The model appears to be a quite broad and flexible platform apt to perform a long list of experiments, few of which have been presented above, studying the outcomes of different policies and different institutional setups. An obvious direction of development ought to address an explicit account of credit and financial markets (a somewhat germane attempt in this direction is in Delli Gatti et al., 2005, broadly along Stiglitzian lines). This is also a natural step in order to also analyze the real impact of monetary policies.

Another line of inquiry involves the comparison between alternative institutional specifications of the ways technologies are accessed and the ways markets work, somewhat along the lines of the "variety of capitalism" approach (Soskice and Hall, 2001). More generally, we view this as an example of a broader research program whereby explicit behavioral microfoundations nest the exploration of the relations between innovative dynamics, demand generation, and policies affecting both.

Finally, one could think to extend the model specification in order to take on board the possibility that agents respond to the state of the system by endogenously adapting their behavioral rules. In fact, as it happens in the majority of ABMs, agents in our model employ behavioral rules that remain fixed throughout the observed econometric sample size, in terms of both their parameters and functional specification. For example, adaptation of rules may be introduced in the model by endogeneizing some parameters currently governing agents behaviors and make them sensible to macroeconomic variables and the institutional framework. This may allow one to study the effectiveness of policy measures in the presence of agents that actively respond to their introduction and tuning.

\section{Acknowledgments}

Thanks to Bruno Amable, Mario Cimoli, Herbert Dawid, Andrea Ginzburg, Paola Giuri, Jean-Olivier Herault, Eckhard Hein, David Lane, Stan Metcalfe, Andreas Pyka, Pier Paolo Saviotti, Bob Solow, Bart Verspagen, and an anonymous referee for their comments and suggestions. Thanks also to the participants to the 12th International Joseph A. Schumpeter Society conference, Rio de Janeiro, Brazil; the 14th International Conference on Computing in Economics and Finance, Paris, France; the 12th conference of the Research Network Macroeconomics and Macroeconomic Policies on "Macroeconomic Policies on Shaky Foundations-Whither Mainstream Economics?", Berlin, Germany; the "Economics of Innovative Change" summer school organized by the Max Planck Institute and the Friedrich Schiller University, Jena, Germany; the "AgentBased Models in Economic Policy Advice" workshop in Mannheim, Germany; and the seminars held at Oxford University, and Paris I, France. Previous versions of the paper have also benefited from comments received during the 5th International Globelics conference, Saratov, Russia; "The Economics of Technology Policy" conference at Monte Verità, Ascona, Switzerland; the 5th International EMAEE conference, Manchester, U.K.; the Brisbane Club Meeting, Pollenzo, Italy; and the "Institutional and Social Dynamics of Growth and Distribution" conference, Lucca, Italy. The research that has led to this work has been supported by the EU FP6 STREP Project "CO3 Common Complex Collective Phenomena in Statistical 
Mechanics, Society, Economics, and Biology" and by the European Union NoE DIME. G.D. and G.F. gratefully acknowledge financial support from PRIN Projects (Italian Ministry of University). All usual disclaimers apply.

\section{References}

Acemoglu, D., Aghion, P., Zilibotti, F., 2006. Distance to frontier, selection, and economic growth. Journal of the European Economic Association 4, 37-74.

Aghion, P., Angeletos, M., Banerjee, A., Manova, K., 2010. Volatility and growth: credit constraints and the composition of investment. Journal of Monetary Economics 57, 246-265.

Aghion, P., Askenazy, P., Berman, N., Cette, G., Eymard, L., 2008. Credit constraints and the cyclicality of r\&d investment: evidence from France. Working Paper 2008-26, Paris School of Economics.

Aghion, P., Howitt, P., 1992. A model of growth through creative destruction. Econometrica 60, 323-351.

Aghion, P., Howitt, P., 1998. Endogenous Growth. MIT Press, Cambridge.

Aghion, P., Howitt, P., 2007. Appropriate growth policy: a unifying framework. Journal of the European Economic Association 4, 269-314.

Aghion, P., Marinescu, I., 2007. Cyclical budgetary policy and economic growth: What do we learn from oecd panel data? NBER Macroeconomics Annual 2007, vol. 22; 2007, pp. 251-278.

Akerlof, G.A., 2002. Behavioral macroeconomics and macroeconomic behavior. American Economic Review 92, 411-433.

Akerlof, G.A., 2007. The missing motivation in macroeconomics. American Economic Review 97, 5-36.

Akerlof, G.A., Yellen, J.L., 1985. A near-rational model of the business cycles, with wage and price inertia. Quarterly Journal of Economics 100, 823-838.

Bartelsman, E., Doms, M., 2000. Understanding productivity: lessons from longitudinal microdata. Journal of Economic Literature 38, 569-594.

Bartelsman, E., Scarpetta, S., Schivardi, F., 2005. Comparative analysis of firm demographics and survival: evidence from micro-level sources in oecd countries. Industrial and Corporate Change 14, 365-391.

Baxter, M., King, R., 1999. Measuring business cycle: approximate band-pass filter for economic time series. The Review of Economics and Statistics 81 , 575-593.

Benhabib, J., Spiegel, M., 1994. The role of human capital in economic development: evidence from aggregate cross-country data. Journal of Monetary Economics 34, 143-173.

Blanchard, O., 2009. The state of macro. Annual Review of Economics 1, 209-228.

Bottazzi, G., Secchi, A., 2003. Common properties and sectoral specificities in the dynamics of U.S. manufacturing firms. Review of Industrial Organization 23, 217-232.

Bottazzi, G., Secchi, A., 2006. Explaining the distribution of firm growth rates. RAND Journal of Economics 37, 235-256.

Caballero, R.J., 1999. Aggregate investment. In: Taylor, J., Woodford, M. (Eds.), Handbook of Macroeconomics. Elsevier Science, Amsterdam.

Canova, F., 2008. How much structure in empirical models. In: Mills, T., Patterson, K. (Eds.), Palgrave Handbook of Econometrics, vol. 2. Applied Econometrics. Palgrave Macmillan.

Castaldi, C., Dosi, G., 2009. The patterns of output growth of firms and countries: scale invariances and scale specificities. Empirical Economics 37 , 475-495.

Caves, R., 1998. Industrial organization and new findings on the turnover and mobility of firms. Journal of Economic Literature 36, 1947-1982.

Ciarli, T., Lorentz, A., Savona, M., Valente, M., 2008. Structural change of production and consumption: a micro to macro approach to economic growth and income distribution. LEM Papers Series 2008/08, Laboratory of Economics and Management (LEM), Sant'Anna School of Advanced Studies, Pisa, Italy.

Colander, D. (Ed.), 2006. Post Walrasian Macroeconomics. Cambridge University Press, Cambridge.

Colander, D., Howitt, P., Kirman, A.P., Leijonhufvud, A., Mehrling, P., 2008. Beyond dsge models: toward an empirically based macroeconomics. American Economic Review 98, 236-240.

Dawid, H., 2006. Agent-based models of innovation and technological change. In: Tesfatsion, L., Judd, K. (Eds.), Handbook of Computational Economics II. North-Holland, Amsterdam.

Dawid, H., Gemkow, S., Harting, P., Kabus, K., Neugart, M., Wersching, K., 2008. Skills, innovation, and growth: an agent-based policy analysis. Journal of Economics and Statistics 228, 251-275.

Deissenberg, C., van der Hoog, S., Dawid, H., 2008. Eurace: a massively parallel agent-based model of the European economy. Applied Mathematics and Computation 204, 541-552.

Del Boca, A., Galeotti, M., Himmelberg, C.P., Rota, P., 2008. Investment and time to plan and build: a comparison of structures vs. equipment in a panel of Italian firms. Journal of the European Economic Association 6, 864-889.

Delli Gatti, D., Di Guilmi, C., Gaffeo, E., Giulioni, G., Gallegati, M., Palestrini, A., 2005. A new approach to business fluctuations: heterogeneous interacting agents, scaling laws and financial fragility. Journal of Economic Behavior and Organization 56, 489-512.

Dinopoulos, E., Segerstrom, P., 1999. A schumpeterian model of protection and relative wages. American Economic Review 89, $450-472$.

Doms, M., Dunne, T., 1998. Capital adjustment patterns in manufacturing plants. Review Economic Dynamics 1, 409-429.

Dosi, G., 1988. Sources, procedures and microeconomic effects of innovation. Journal of Economic Literature 26, 126-171.

Dosi, G., 2007. Statistical regularities in the evolution of industries. A guide through some evidence and challenges for the theory. In: Malerba, F., Brusoni, S. (Eds.), Perspectives on Innovation. Cambridge University Press, Cambridge, MA.

Dosi, G., Fabiani, S., Aversi, R., Meacci, M., 1994. The dynamics of international differentiation: a multi-country evolutionary model. Industrial and Corporate Change 3, 225-242.

Dosi, G., Fagiolo, G., Roventini, A., 2006a. An evolutionary model of endogenous business cycles. Computational Economics 27, 3-34.

Dosi, G., Marengo, L., Pasquali, C., 2006b. How much should society fuel the greed of innovators? On the relations between appropriability, opportunities and rates of innovation. Research Policy 35, 1110-1121.

Dosi, G., Fagiolo, G., Roventini, A., 2008. The microfoundations of business cycles: an evolutionary, multi-agent model. Journal of Evolutionary Economics $18,413-432$

Dosi, G., Marsili, O., Orsenigo, L., Salvatore, R., 1995. Learning, market selection and the evolution of industrial structures. Small Business Economics 7 , 411-436.

Eisner, R., 1972. Components of capital expenditures: replacement and modernization versus expansion. The Review of Economics and Statistics 54, 297-305.

Fabiani, S., Druant, M., Hernando, I., Kwapil, C., Landau, B., Loupias, C., Martins, F., Mathä, T., Sabbatini, R., Stahl, H., Stokman, A., 2006. What firms' surveys tell us about price-setting behavior in the euro area. International Journal of Central Banking 2, 3-47.

Fagiolo, G., Dosi, G., 2003. Exploitation, exploration and innovation in a model of endogenous growth with locally interacting agents. Structural Change and Economic Dynamics 14, 237-273.

Fagiolo, G., Dosi, G., Gabriele, R., 2004. Matching, bargaining, and wage setting in an evolutionary model of labor market and output dynamics. Advances in Complex Systems 14, 237-273.

Fagiolo, G., Moneta, A., Windrum, P., 2007. A critical guide to empirical validation of agent-based models in economics: methodologies, procedures, and open problems. Computational Economics 30, 195-226.

Fagiolo, G., Napoletano, M., Roventini, A., 2008. Are output growth-rate distributions fat-tailed? Some evidence from oecd countries. Journal of Applied Econometrics 23, 639-669.

Fagiolo, G., Roventini, A. On the scientific status of economic policy: a tale of alternative paradigms. Knowledge Engineering Review, forthcoming.

Farrel, J., Shapiro, C., 1988. Dynamic competition with switching costs. RAND Journal of Economics 19, $123-137$. 
Feldstein, M., Foot, D., 1971. The other half of gross investment: replacement and modernization expenditures. The Review of Economics and Statistics 53, 49-58. Fogel, K., Morck, R., Yeung, B., 2008. Big business stability and economic growth: Is what's good for General Motors good for America? Journal of Financial Economics 89, 83-108.

Fukac, M., Pagan, A., 2006. Issues in adopting dsge models for use in the policy process. Working Paper 10/2006, CAMA.

Galí, J., Gertler, M., 2007. Macroeconomic modelling for monetary policy evaluation. Journal of Economic Perspectives 21, 25-46.

Goolsbee, A., 1998. The business cycle, financial performance, and the retirement of capital goods. Review of Economic Dynamics 1, 474-496.

Gourio, F., Kashyap, A.K., 2007. Investment spikes: new facts and a general equilibrium exploration. Journal of Monetary Economics 54, 1-22.

Greenwald, B., Stiglitz, J., 1993a. Financial market imperfections and business cycles. Quarterly Journal of Economics 108, 77-114.

Greenwald, B., Stiglitz, J., 1993b. New and old Keynesians. Journal of Economic Perspectives 7, 23-44.

Greenwald, B., Stiglitz, J., 2003. Macroeconomic fluctuations in an economy of phelps-winter markets. In: Aghion, P., Frydman, R., Stiglitz, J., Woodford, M. (Eds.), Knowledge, Information, and Expectations in Modern Macroeconomics: In Honor of Edmund S. Phelps. Princeton University Press, Princeton, NJ.

Hicks, J.R., 1937. Mr. Keynes and the "Classics": a suggested interpretation. Econometrica 5, 147-159.

Hubbard, G.R., 1998. Capital-market imperfections and investment. Journal of Economic Literature 36, $193-225$.

Keynes, J.M., 1936. The General Theory of Employment, Interest, and Money. Prometheus Books, New York.

Kirman, A.P., 1992. Whom or what does the representative individual represent? Journal of Economic Perspectives 6, 117-136

Klemperer, P.D., 1987. Markets with customer switching costs. Quarterly Journal of Economics 102, 375-394.

Klemperer, P.D., 1995. Competition when consumers have switching costs: an overview with applications to industrial organization, macroeconomics and international trade. Review of Economic Studies 62, 515-539.

Klevorick, A.K., Levin, R., Nelson, R.R., Winter, S.G., 1995. On the sources and significance of interindustry differences in technological opportunities. Research Policy 24, 185-205.

Lane, D.A., 1993. Artificial worlds and economics, part i and ii. Journal of Evolutionary Economics 3 89-107 and 177-197.

LeBaron, B., Tesfatsion, L., 2008. Modeling macroeconomies as open-ended dynamic systems of interacting agents. American Economic Review 98, $246-250$.

Louca, F., 2001. Intriguing pendula: founding metaphors in the analysis of economic fluctuations. Cambridge Journal of Economics 25, 25-55.

Malerba, F., Orsenigo, L., 1995. Schumpeterian patterns of innovation. Cambridge Journal of Economics 19, 47-65.

Metcalfe, J.S., 1994a. Competition, fisher's principle and increasing returns to selection. Journal of Evolutionary Economics 4 (327-346).

Metcalfe, J.S., 1994b. Evolutionary economics and technology policy. The Economic Journal 104, 932-944.

Napoletano, M., Roventini, A., Sapio, S., 2006. Are business cycles all alike? A bandpass filter analysis of the Italian and us cycles. Rivista Italiana degli Economisti 1, 87-118

Nelson, R.R., Phelps, E.S., 1966. Investment in humans, technological diffusion, and economic growth. American Economic Review 61, 69-75.

Nelson, R.R., Winter, S.G., 1982. An Evolutionary Theory of Economic Change. The Belknap Press of Harvard University Press, Cambridge.

Neugart, M., 2008. Labor market policy evaluation with ace. Journal of Economic Behavior and Organization 67, 418-430.

Pavitt, K., 1984. Sectoral patterns of technical change: towards a taxonomy and a theory. Research Policy 13, $343-373$.

Phelps, E.S., Winter, S.G., 1970. Optimal price policy under atomistic competition. In: Phelps, E.S. (Ed.), Microeconomic Foundations of Employment and Inflation Theory. Nortonm, New York

Pyka, A., Fagiolo, G., 2007. Agent-based modelling: a methodology for neo-schumpeterian economics. In: Hanusch, H., Pyka, A. (Eds.), The Elgar Companion to Neo-Schumpeterian Economics. Edward Elgar Publishers, Cheltenham.

Romer, P., 1990. Endogenous technical change. Journal of Political Economy 98, 71-102.

Rotemberg, J., 2008. Behavioral aspects of price setting, and their policy implications. Working Paper 13754, NBER.

Rotemberg, J., Woodford, M., 1999. The cyclical behavior of prices and costs. In: Taylor, J., Woodford, M. (Eds.), Handbook of Macroeconomics. Elsevier Science, Amsterdam.

Saviotti, P., Pyka, A., 2008. Product variety, competition and economic growth. Journal of Evolutionary Economics 18, 323-347.

Silverberg, G., Dosi, G., Orsenigo, L., 1988. Innovation, diversity and diffusion: a self-organization model. The Economic Journal 98, $1032-1054$.

Silverberg, G., Verspagen, B., 2005. Evolutionary theorizing on economic growth. In: Dopfer, K. (Ed.), Evolutionary Principles of Economics. Cambridge University Press, Cambridge.

Solow, R.M., 1956. A contribution to the theory of economic growth. Quarterly Journal of Economics 70, 65-94.

Solow, R.M., 2008. The state of macroeconomics. Journal of Economic Perspectives 22, 243-246.

Soskice, D., Hall, P. (Eds.), 2001. Varieties of Capitalism: the Institutional Foundations of Comparative Advantage. Oxford University Press, Oxford.

Stiglitz, J., 1994. Endogenous growth and cycles. In: Shionoya, Y., Perlman, M. (Eds.), Innovation in Technology, Industries, and Institutions. Studies in Schumpeterian Perspectives. Ann Arbor, The University of Michigan Press.

Stiglitz, J., Weiss, A., 1992. Credit rationing in markets with imperfect information. American Economic Review 71, $393-410$.

Stock, J., Watson, M., 1999. Business cycle fluctuations in U.S. macroeconomic time series. In: Taylor, J., Woodford, M. (Eds.), Handbook of Macroeconomics. Elsevier Science, Amsterdam.

Tesfatsion, L., 2000. Structure, behavior, and market power in an evolutionary labor market with adaptive search. Journal of Economic Dynamics \& Control $25,419-457$.

Tesfatsion, L., Judd, K. (Eds.), 2006. Handbook of Computational Economics II: Agent-Based Computational Economics. North-Holland, Amsterdam.

Verspagen, B., 2002. Evolutionary macroeconomics: a synthesis between neo-schumpeterian and post-keynesian lines of thought. The Electronic Journal of Evolutionary Modeling and Economic Dynamics $1007\langle$ http://www.e-jemed.org/1007/index.php 〉.

Woodford, M., 2003. Interest and Prices: Foundations of a Theory of Monetary Policy. Princeton University Press, Princeton, NJ. 